\title{
Deals Versus Rules: Policy Implementation Uncertainty and Why Firms Hate It
}

\section{Citation}

Hallward-Driemeier, Mary, Gita Khun-Jush, and Lant Pritchett. 2010. Deals Versus Rules: Policy Implementation Uncertainty and Why Firms Hate It. HKS Faculty Research Working Paper Series, RWP10-027, John F. Kennedy School of Government, Harvard University. Previously published in Working Paper Series, 16001, National Bureau of Economic Research Working Papers, 2010.

\section{Published Version}

http://web.hks.harvard.edu/publications/workingpapers/citation.aspx?Publd=7343

\section{Permanent link}

http://nrs.harvard.edu/urn-3:HUL.InstRepos:4448884

\section{Terms of Use}

This article was downloaded from Harvard University's DASH repository, and is made available under the terms and conditions applicable to Other Posted Material, as set forth at http:// nrs.harvard.edu/urn-3:HUL.InstRepos:dash.current.terms-of-use\#LAA

\section{Share Your Story}

The Harvard community has made this article openly available.

Please share how this access benefits you. Submit a story.

Accessibility 


\section{Deals Versus Rules: Policy \\ I mplementation Uncertainty and Why Firms Hate It Faculty Research Working Paper Series}

\section{Mary Hallward-Driemeier}

World Bank

\section{Gita Khun-Jush}

University of Chicago

\section{Lant Pritchett}

Harvard Kennedy School

\section{J une 2010 \\ RWP10-027}

\footnotetext{
The views expressed in the HKS Faculty Research Working Paper Series are those of the author(s) and do not necessarily reflect those of the John F. Kennedy School of Government or of Harvard University. Faculty Research Working Papers have not undergone formal review and approval. Such papers are included in this series to elicit feedback and to encourage debate on important public policy challenges. Copyright belongs to the author(s). Papers may be downloaded for personal use only.
} 
DEALS VERSUS RULES:

POLICY IMPLEMENTATION UNCERTAINTY AND WHY FIRMS HATE IT

\author{
Mary Hallward-Driemeier \\ Gita Khun-Jush \\ Lant Pritchett \\ Working Paper 16001 \\ http://www.nber.org/papers/w16001
}

\author{
NATIONAL BUREAU OF ECONOMIC RESEARCH \\ 1050 Massachusetts Avenue \\ Cambridge, MA 02138
}

May 2010

We would like to thank the NBER for support via the Africa Project. We would like to thank Bill Battaile, Asli Demirguc-Kunt, Ahmed Galal, Ricardo Hausmann, Marialisa Motta, Stephen O'Connell, Rita Ramalho, James Robinson, Dani Rodrik, Luis Serven, Andrei Shleifer, Sylvia Solf and David Weil for conversations that were, perhaps unbeknownst to them, helpful and to Dan Willey for motivation on this topic. Mamadou Bady Balde provided the materials on Rwanda. The views expressed here do not necessarily represent the views of the World Bank, its Executive Directors, or the National Bureau of Economic Research.

(C) 2010 by Mary Hallward-Driemeier, Gita Khun-Jush, and Lant Pritchett. All rights reserved. Short sections of text, not to exceed two paragraphs, may be quoted without explicit permission provided that full credit, including $\odot$ notice, is given to the source. 
Deals versus Rules: Policy Implementation Uncertainty and Why Firms Hate It

Mary Hallward-Driemeier, Gita Khun-Jush, and Lant Pritchett

NBER Working Paper No. 16001

May 2010

JEL No. D81,H32,J23,K2,O17

\begin{abstract}
$\underline{\text { ABSTRACT }}$
Firms in Africa report "regulatory and economic policy uncertainty" as a top constraint to their growth. We argue that often firms in Africa do not cope with policy rules, rather they face deals; firm-specific policy actions that can be influenced by firm actions (e.g. bribes) and characteristics (e.g. political connections). Using Enterprise Survey data we demonstrate huge variability in reported policy actions across firms notionally facing the same policy. The within-country dispersion in firm-specific policy actions is larger than the cross-national differences in average policy. We show that variability in this policy implementation uncertainty within location-sector-size cells is correlated with firm growth rates. These measures of implementation variability are more strongly related to lower firm employment growth than are measures of "average" policy action. Finally, we show that the de jure measures such as Doing Business indicators are virtually uncorrelated with ex-post firm-level responses, further evidence that deals rather than rules prevail in Africa. Strikingly, the gap between de jure and de facto conditions grows with the formal regulatory burden. The evidence also shows more burdensome processes open up more space for making deals; firms may not incur the official costs of compliance, but they still pay to avoid them. Finally, measures of institutional capacity and better governance are closely associated with perceived consistency in implementation.
\end{abstract}

Mary Hallward-Driemeier

World Bank

1818 H Street, NW

Washington, DC 20433

mhallward@worldbank.org

Gita Khun-Jush

University of Chicago

5416 S. Woodlawn Avenue

Chicago, IL 60615

gkhunjush@uchicago.edu
Lant Pritchett

Harvard Kennedy School

79 JFK St.

Cambridge, MA 02138

lant_pritchett@harvard.edu 


\section{Deals versus Rules: \\ Policy Implementation Uncertainty and Why Firms Hate it}

For my friends, anything; for my enemies, the law.

Oscar R. Benavides, President of Peru, 1933-1940

\section{Introduction}

The Investment Climate Enterprise Surveys have conducted detailed face-to-face interviews of over 80,000 entrepreneurs in over 100 countries, including 11,150 in 34 Sub-Saharan countries. The issue firms most frequently identify as an obstacle to their growth is "regulatory and economic policy uncertainty" (Smith and Hallward-Driemeier 2005). In Africa, 60 percent of surveyed firms regard “economic and regulatory policy uncertainty” as an obstacle to their firms' growth and almost 40 percent regard it as a “severe” or "major” obstacle (figure 1). This finding creates a puzzle. The other obstacles in the top 5 of Figure 1 are easy to understand: lack of electricity creates obvious production problems, macro-economic instability has its obvious consequences, firms everywhere and always complain about taxes, and “access to finance” as been widely investigated as a limit to firm expansion. Moreover, these other obstacles-infrastructure, macroeconomic instability, access to finance--are relatively easily linked to related literatures on country aggregate growth and to programmatic activities. But until we understand what "regulatory and policy uncertainty," is, such that firms hate it so, we cannot investigate its impacts at the aggregate level nor what could be done about it. 
Figure 1: "Policy Uncertainty" is commonly identified by firms as a "severe" or "major" obstacle to firm growth in Africa

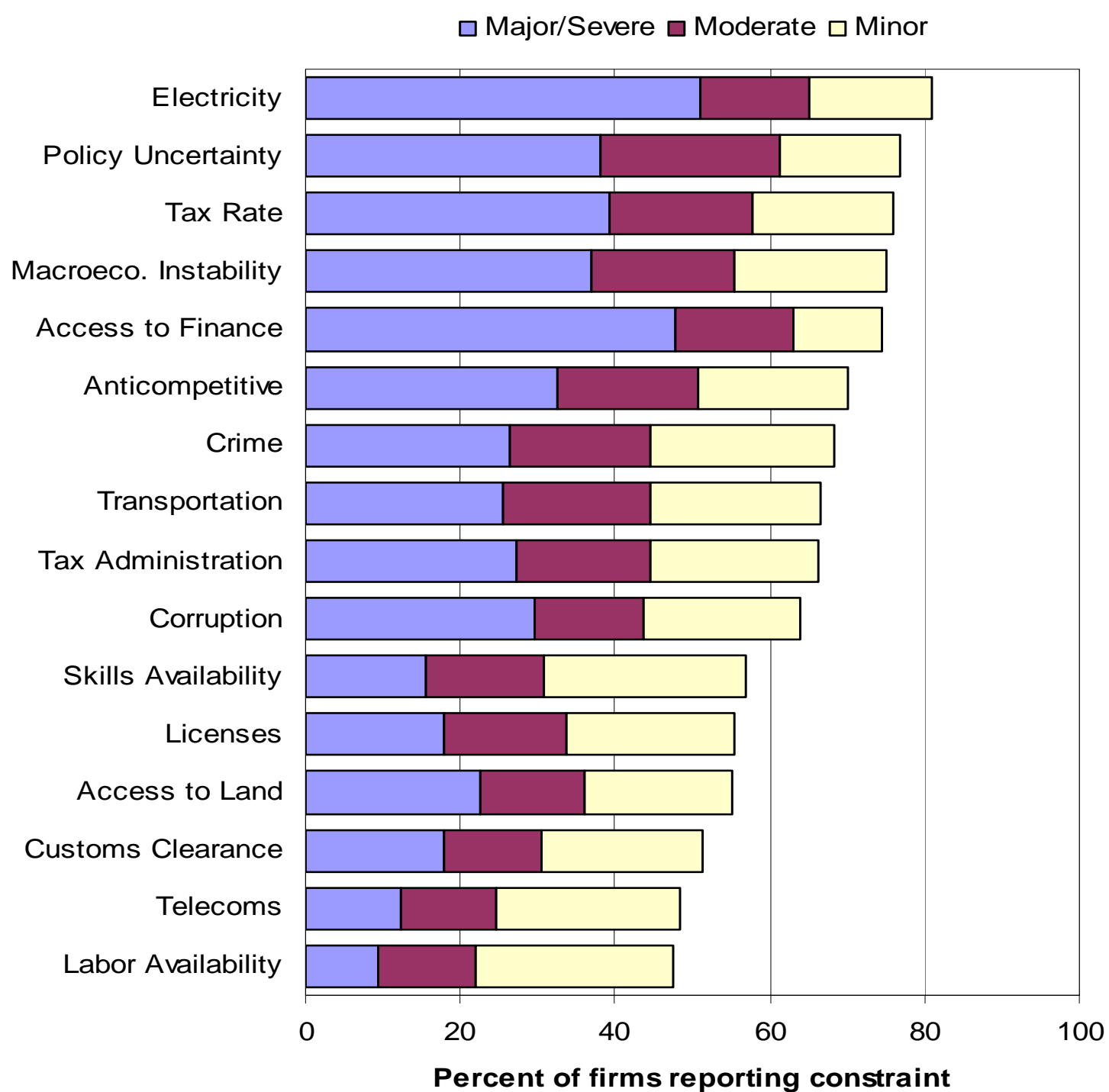

Source: Author's analysis using Enterprise Surveys in 2002-2005 ${ }^{1}$

One view is that firms are concerned about a lack of political and policy making stability which leads to frequent and unpredictable changes in the formal rules and de

\footnotetext{
1 "Policy uncertainty" as one of the potential constraints was not included in the later surveys; it was changed to "political uncertainty" which gets much lower ratings. This chart reflects the responses of 3317 firms in 13 countries. Data presented in the rest of the paper uses the full sample of firm responses in SubSaharan Africa.
} 
jure policies ${ }^{2}$. We argue for a different interpretation of firms' complaints. Firm profitability is not directly affected by "policy" but rather by policy actions taken by agents of the state in the course of policy implementation. In the weak organizational and institutional environments for policy implementation which are common across Africa, policy does not predict policy implementation actions at the firm level. Even when policy is unchanging and even when there is macroeconomic stability, firms face massive risk and uncertainty about their operations and profitability due to variability in policy actions that result from the weak capability for implementation of regulatory and economic policy.

The evidence of variation in the implementation of policy is striking. We show for a number of specific policy outcomes - getting an operating license, getting a construction permit, clearing goods through customs - that the variation within country is much greater than the variation across countries. Studies that focus on measures of country averages are thus missing where most of the action is.

This variation in implementation in turn is associated with greater activities on the part of firms to influence the outcomes (e.g. paying bribes or spending time with officials). Rather than coping with the application of (more or less favorable) rules, the evidence indicates firms in Africa face deals. The policy actions actually taken are influenced by actions (e.g. bribes) and characteristics (e.g. political connections) of the firm. However deals do not assure a certain outcome. Deals themselves create ex ante or ex post uncertainty to a differing extent depending on whether deals are ordered or

\footnotetext{
${ }^{2}$ Another view is that firms are complaining about the inter-temporal uncertainty and volatility in overall economic conditions created by poor macroeconomic policy_but "macroeconomic instability" is a separately identified obstacle.
} 
disordered, and whether these deals are open to all firms or deal-making opportunities are closed (i.e. only open to firms with certain characteristics).

The firm level evidence also shows why firms hate uncertainty. Variations in policy outcomes are correlated with lower firm employment growth. In fact, it is the variations themselves rather than the average level of policy outcome that is associated with firm performance. We then use a "differences in differences" approach to show policy implementation uncertainty has a greater relative effect on firms that are more susceptible to policy uncertainty.

Finally, we show that, in Africa, there is almost no connection between firm reported policy actions and de jure policies (e.g. as measured by Doing Business) across countries. Knowing the Doing Business measure, i.e. how long a procedure is formally supposed to take, provides no power in explaining how long it will actually take a firm to complete the procedure. Doing Business is not aiming to measure what actually happens, but what is supposed to happen. That there is little relationship between the two is further evidence of the role of deals in shaping the conditions firms actually face. And, telling, the gap between the de jure and de facto measures grows with the burdens or delays implied in the formal rules. The space for deals thus grows with the burden of the regulatory requirements.

This finding, however, raises questions about whether reforming the formal rules will have much impact. ${ }^{3}$ If a rule is not being applied, changing it may have little impact. But it could still reduce costs if the space for deals shrinks and firms need to incur lower

\footnotetext{
${ }^{3}$ The Doing Business project rightly points out that the regulatory requirements can be excessively burdensome in some countries. Simplification of the regulations can remain a worthy goal - with added benefits of reducing the institutional capacity needed for implementation and likely helping close some of the opportunities for bribes.
} 
costs of avoiding the less burdensome formal requirements. Simplifying the rule could even be associated with longer times reported by firms if compliance actually goes up in the wake of reforms. ${ }^{4}$ In looking for impact, the role of institutional quality appears to help predict the range of reported firm outcomes. Where institutional quality is higher, rules are more likely to be implemented, and so changes in rules will more likely be reflected in the conditions firms face. This insight helps reconcile the "institutions rule" evidence on aggregate performance with the mixed success of "policy reform."

The paper is organized as follows. The second section elaborates on the distinctions between policy, policy implementation and policy actions. The third section then develops in greater detail the framework for thinking about policy uncertainty, focusing on the gap between de jure rules and actual implementation, and the behaviors firms engage in to shape the actions taken by agents of the state.

The third and fourth sections of the paper look at the evidence provided by firm surveys of 11,150 firms in 34 countries in Africa. It looks at the variation in policy outcomes as reported by firms, and relates that variation to deal making activities and to firm performance. Section four focuses on three specific regulatory areas: getting a construction permit, getting an operating license and clearing customs. It shows the lack of relationship between the de jure and de facto policies indicating the prevalence of deals, and that this gap grows with the de jure delays and burdens of the regulations. It also relates the findings to broader debates about institutional capacity and discusses possible avenues for reducing implementation uncertainty.

\footnotetext{
${ }^{4}$ In additional work we are testing the impact using the time series data; here the results are based on crosssectional variation. (Hallward-Driemeier and Pritchett 2010).
} 


\section{I) Policy, Policy Implementation and Policy Actions}

The conceptual distinction can be illustrated with the example of a seemingly simple policy, like an import tariff. With strong capability for implementation a firm's import tax payments actually collected (the policy action) are well-predicted by the firm's import value (a factual state of the world) and the tariff code (the rule or mapping between states of the world (sales) and policy actions (tax to be collected)). In a study of Kenya's import tariff revenues Pritchett and Sethi (1994) compared the ad valorem collected rate (ratio of revenue collected to declared import value) to the actual ad valorem rate for the 3,392 separate items of the tariff code. There was surprisingly little connection as items with the same official rate had very different collected rates ${ }^{5}$. For instance, of the 435 items in the tariff code with an ad valorem tariff of 40 percent (which recorded positive imports) the $25^{\text {th }}$ percentile of the collected rate was zero, the mean was 20 percent and the $75^{\text {th }}$ percentile was 24 percent. An item's tariff rate had very little predictive power for the tariff actually paid due to a large number of officially sanctioned deviations due to exemptions for certain purposes, exemption of certain importers, etc. which meant that even if two firms were importing exactly the same item they might pay completely different rates. ${ }^{6}$

A recent study of the acquisition of driver’s licenses in Delhi, India (Bertrand,

\footnotetext{
${ }^{5}$ While naively one might imagine a regression of ad valorem revenue on ad valorem rates might yield a coefficient of 1 and an R-squared near one (e.g. items with a 20 percent rate would have 20 percent collection rates and items with 30 percent would have a 30 percent collection rate (this is not about demand elasticity as this is normalized by import value). Instead, across a variety of functional forms the official rate could only explain about a fifth of the observed variation across items in the collected rate. Of course this potentially vastly overstates the connection between the official tariff and tariff collected on the actual import of specific items as it does not include smuggling or mis-declaration.

${ }^{6}$ If exceptions are formally recognized and there are enough of them, then the lack of correlation on the non-exempted tariffs and actual revenue could be an example of the rules actually being applied. However, the variations within narrow ranges of goods are too great. Rather, the existence of such exemptions themselves indicates that deals were sought - and granted.
} 
Djankov, Hanna and Mullainathan 2007) also illustrates nicely the conceptual distinctions between policy, policy implementation and a policy action. The policy in Delhi stipulates the standard requirements for a driver's license: proof of identity, age, residence, and demonstrated competence in driving. The policy also stipulates the formal procedures for implementation: the organization responsible for issuing driver’s licenses and the criteria they are to use in assessing whether or not an individual meets the requirements, e.g. the standards of proof for age, and the contents of the examination to assess driving competence. Actual policy implementation was investigated by asking people on their way into the building to get a driver's license to cooperate in a study of the process. The subjects were divided into a control group and two treatment groups (one of which was given a bonus if they got their license faster and one of which was given free driving lessons to improve their driving skills). The control group results are interesting in their own right. First, most people in the control group hired a private agent to handle the process for them. Second, only 12 percent of the control group who hired an agent took the driver's examination required by policy--but the policy action was that they received a license anyway. In contrast, 94 percent of control group people who did not hire an agent were required to take the driving exam and many were failed ${ }^{7}$. Clearly in the process of policy implementation states of the world that mattered according to the policy rule (knowing how to drive) did not matter in determining the policy action for individuals while states of the world that did not matter in the policy rule (paying a tout)

\footnotetext{
${ }^{7}$ At least in their first attempt, many then learned and hired an agent and got their license that
} way. The study also documents that the public policy purpose of the driving examination was subverted by the exemption from the exam. They hired a firm that teaches driving in Delhi to independently assess the driving competence of those who received licenses and found that, of those in the control group that hired an agent and got a license 69 percent were “automatic” failures in a driving test. 
did matter in determining the policy action ${ }^{8}$.

In an idealized "rules” world policies are predictive of policy actions as the implemented policy action is in each instance the result of the application of the policy mapping between factual states of the world and the actions stipulated by the policy and nothing else- - the rules are the rules. In a “deals” environment policy actions are the result of not just the policy rule but also potentially the lack of organizational capability for enforcement, inadequate technical capacity of front-line implementers, self-interest of the agents of the government at all levels (politicians and bureaucrats), as well as actions and characteristics of firms. In a sufficiently weak environment everything is potentially uncertain and/or negotiable. While negotiated firm specific deals have some positive effects in freeing firms from the worst consequences of unreasonable rules, the nature of the environment for deals can potentially create the types of policy implementation uncertainty that inhibits transactions, investments, firm growth, and productivity.

\section{II) The Varieties of "Policy Uncertainty"?}

Things should be as simple as possible, but no simpler.

Albert Einstein

Firm outcomes, such as profitability, revenue growth, and hence firm choices are affected by the actual and anticipated policy actions taken by agents of the state. Policy actions are choices made by the agents responsible for policy implementation. We call the way firms form their expectations of future policy actions a positive model of implemented policy (PMIP). If firms have, and complain of, policy uncertainty this

\footnotetext{
${ }^{8}$ Another interesting finding of the study is that not all elements of the policy were equally subverted: hiring a tout could easily get you out of taking the driving exam but not so easily get you out of having the right documentation.
} 
implies that firms have, at least implicitly, probability distributions over future policy

actions. Economic agents make both business decisions (e.g. investments, product choice, technique of production, number of workers to hire, who to contract with, whether to comply with regulations) and policy implementation influence decisions (e.g. how much to offer as a bribe, which politician to befriend, whether to register or remain informal) based on their PMIP, which maps from states of the world to distributions of policy actions, distributions which naturally both central tendencies and dispersions. We are not going to impose much structure (e.g. rationality, optimality, completeness) on firms' PMIPs, rather we only use the concept to provide distinctions needed to distinguish the relevant types of policy uncertainty, which we then attempt to illustrate and disentangle empirically in section II and document the impacts of policy uncertainty on one dimension of firm performance, job growth, in section $\mathrm{III}^{9}$.

A notional policy mapping (NPM) is one element of a PMIP. We define this as the officially declared mapping from specified contingent factual conditions about the world to actions by an agent of the state $e^{10}$. With perfect enforcement "rules are the rules” and hence the predicted policy action for any firm is a function only of the administratively relevant state of the world. Under perfect enforcement (and perhaps therefore full compliance as an equilibrium choice of firms) ${ }^{11}$ there is a natural conflation

\footnotetext{
${ }^{9}$ Pritchett (2005) has a much fuller discussion of the elements of positive models of implemented policy. ${ }^{10}$ A completely fixed action that is not contingent is just a special case in which the mapping is from all states of the world into the same policy action (e.g. a $k$ percent money growth).

${ }^{11}$ Given the PMIP each firm also makes compliance decisions. With additional assumptions about probabilities of detection one can produce an equilibrium in which the optimizing calculation of all agents, both agents of the state in implementation and economic agents, is compliance and firm voluntary truthful disclosure and compliance is the equilibrium strategy. But even if the rules are not susceptible to influence firms might try to avoid the rules, even with the expectation that if detected the rules (including penalties for non-compliance) will be enforced. We often get parking tickets but never try and bribe the meter maid. But, without explicit limitations on implementation capacity one can nearly always specify an enforcement mechanism that induces compliance as an equilibrium strategy.
} 
of "policy" with the notional policy mapping in that it is assumed all firms have the same PMIP and that each firms PMIP is the NPM, all firms share the positive prediction that the NPM predicts policy actions conditional on states of the world independently of the firm's influence activities or characteristics. This assumption is common, such as the seemingly innocuous expression of a firm's net of sales tax revenue as their sales less their sales times the sales tax rate:

$$
\text { Revenue }^{i}=\text { Sales }^{i}-\tau^{*} \text { Sales }^{i}
$$

This simple equation assumes that the actually tax rate paid is common across all firms and that reported sales and actual sales are equal.

"Rules are the rules" is not a terrible first approximation in many policy domains for many firms in countries with strong implementation capability. Firms expect their property tax to determined by the administratively declared valuation and the property tax rate, their feasible land-use to be determined by zoning, their labor contracts (e.g. minimum wage) to be determined by the labor law—and expect this with relatively little variation $^{12}$. Of course, even in strong implementation countries there is regulatory capture (including "intellectual capture") in some policy domains that influences implementation for favored firms or industries ${ }^{13}$. Moreover, in many policy domains even in countries with "good" implementation environments there is often substantial uncertainty in determining the "state of the world" creating ample room for both extended regulatory disputes, civil lawsuits, and scope for deals—-there are after all

\footnotetext{
${ }^{12}$ Or at least expect variation of predictable types. I may think the probability of getting a speeding ticket might be low, even if I drive above the limit, but have essentially zero expectation of getting a speeding ticket if I am factually driving exactly the speed limit. So while there is "uncertainty" about enforcement it is of a predictable type.

${ }^{13}$ Johnson (2009) argues both the financial crisis in the United States and the responses to that crisis are an illustration of garden variety control of segment of elites over the policy process seen in many developing countries.
} 
850,000 lawyers in the USA.

In the idealized "rules are the rules" world, conditional on the NPM and the states of the world, there is little policy action uncertainty from implementation. In this case the major form of "policy uncertainty" would be inter-temporal uncertainty in the notional policy mapping.

In Sub-Saharan Africa the NPM or de jure rules are only one element of a firm's PMIP. We define a policy deal as firm specific policy implementation (in one or more policy domains) that results in policy actions that differ from what would have happened under perfect enforcement and/or full compliance. ${ }^{14} \mathrm{~A}$ deal might explicitly create separate conditions for a firm or project—e.g. waiving compliance with certain regulations, creating special definitions. Deals can be across policy domains for a specific firm, such firms with politically powerful patrons who are then treated differently in all regulations (e.g. with the tax collector, the safety regulation, land use, labor, etc.). Deals might just allow the firm to do in a timely manner what is allowed under the rules so the deal simply avoids a delay that might be longer than perfect enforcement. Some policies essentially require deals, as when the policy is conditioned on subjective or non-verifiable characteristics or intended to achieve policy goals for which there is no consensus model (e.g. land use for which zoning waivers are available for certain purposes, "high bandwidth" industrial policies to promote innovation). Influencing deals may take the form of pure persuasion, meeting with government agents

\footnotetext{
${ }^{14}$ This is analogous to descriptions of transactions between private individuals. Completed transactions between individuals that are routine and hence involve no specificity are not typically referred to as "deals"-if I buy a dozen eggs from the grocery store it would be odd to say I completed a "deal" with the grocery store of money for eggs. There is another entire literature about Africa how weak environments for transactions (including the inability to rely on government for disinterested and objective third party enforcement of private deals) lead greater portions of economic activities to be carried out as "deals" involving specific characteristics rather than as routine arms-length transactions (e.g. Fafchamps 2004).
} 
to induce a favorable decision even without illicit consideration of any type. Deals can also be the result of illicit collusion, paying direct bribes, donations, favors. Deals can be large — between a firm and the president of the country or small between a person running a tortilla stand on the side of the road and the local police officer/precinct or anywhere in between. We also consider subterfuge as a type of deal, altering the policy action through attempting to avoid the implementing agents, hide sales or assets, or remain entirely unregulated through "informal” status, particularly if the agents are willing to play along or avoid investigations. We intend the word "deal" as descriptive of the firm level hyper-specific nature of the implemented policy actions and do not intend the contrast with "rules" to necessarily have pejorative connotations ("getting a deal" or "reaching a deal" are usually positive).

In modeling, simple is good, but too simple is bad and "rules are the rules" is far too simple understand why African firms say they hate "policy uncertainty." Firms operating in countries with weak implementation capability must have PMIPs (mappings from states of the world to distributions of policy actions) that are more complex than "rules are the rules" (or alternatively that the NPM is the PMIP) in three ways. First, firms pursue actions to influence policy actions and hence their PMIP must provide a mapping not just between factual states of the world and policy actions but also between influence activities of the firm (e.g. lobbying, bribes, evasion, meeting with officials, hiring facilitators) and policy actions, even conditional on the "facts"" implementation may depend not just on the actions of the firms but also their characteristics, so that a PMIP is, at least potentially, heterogeneous across firms, even in

\footnotetext{
${ }^{15}$ This is distinct from the usual discussion of the changes in behavior induced by the regulation, along the lines of the tax aversion (avoiding taxed activities) versus tax evasion (avoiding tax on activities) distinction.
} 
the same country and sector. Third, firms face a variety of regulations and hence have to consider the connections across regulatory domains (e.g. becoming a legally recognized firm may bring the attention of tax authorities, getting a bank loan may require land-use registration) which may not share PMIPs.

To discuss how deals translate into policy implementation uncertainty for firms we need two further distinctions in the policy domain specific environment for deals. The first is whether the deals environment is "ordered" or "disordered." 16 The second is whether deals environment is “open” (available to all firms) or “closed” (deals are available depending on firm characteristics and/or a limited number of deals are available). The distinction between rules and deals and the distinctions among deal environments (discussed more fully below) creates five possible categories: rules, open ordered deals, closed ordered deals, open disordered deals, closed disordered deals. These produce conceptually different sources of "regulatory and economic policy uncertainty” and potentially distinct magnitudes of this as a concern to firms (Table 1).

\footnotetext{
${ }^{16}$ This is closely related to the distinction of Shleifer and Vishny (1993) between "organized" and “disorganized" corruption.
} 


\begin{tabular}{|c|c|c|}
\hline \multicolumn{3}{|c|}{$\begin{array}{l}\text { Table 1: Relationship between rules, types of deal environments (open versus } \\
\text { closed, ordered versus disordered) and the associated type of "regulatory and } \\
\text { economic policy uncertainty" }\end{array}$} \\
\hline \multicolumn{3}{|c|}{$\begin{array}{c}\text { Rules } \\
\text { Uncertainty of type (a) inter-temporal changes in the notional policy mapping (formal } \\
\text { rules) }\end{array}$} \\
\hline \multicolumn{3}{|c|}{$\begin{array}{l}\text { Deals } \\
\text { (Implemented policy actions depend on factors, including characteristics or actions of the } \\
\text { firm, not specified in the notional policy mapping) }\end{array}$} \\
\hline & $\begin{array}{c}\text { Open } \\
\text { (deals are available to all } \\
\text { firms) }\end{array}$ & $\begin{array}{l}\text { Closed } \\
\text { (deals are available only to } \\
\text { favored firms) }\end{array}$ \\
\hline \begin{tabular}{l}
\multicolumn{1}{c}{ Ordered } \\
(small ex-post uncertainty \\
about policy \\
implementation—deals stay \\
done)
\end{tabular} & $\begin{array}{l}\text { (a) and } \\
\text { (b) uncertainty about the } \\
\text { "influence function" and } \\
\text { (c) uncertainty about the } \\
\text { reliability and durability } \\
\text { of deals }\end{array}$ & $\begin{array}{l}\text { (a) and (b) and (c) and } \\
\text { (d) uncertainty about which } \\
\text { type of treatment a firm will } \\
\text { receive depending on its } \\
\text { characteristics } \\
\text { (firms have differential ex } \\
\text { ante (type b) and ex post } \\
\text { (type c) uncertainty } \\
\text { depending on } \\
\text { characteristics) }\end{array}$ \\
\hline \begin{tabular}{l}
\multicolumn{1}{c}{ Disordered } \\
(large ex-post uncertainty- \\
deals cannot secure \\
predictability)
\end{tabular} & $\begin{array}{l}\text { (a) and Type b } \\
\text { uncertainty is much larger } \\
\text { as the "influence } \\
\text { function" is less known } \\
\text { and type c uncertainty is } \\
\text { much larger as deals do } \\
\text { not stay done (as other } \\
\text { parties may intervene) }\end{array}$ & $\begin{array}{l}\text { (a) and Type b uncertainty } \\
\text { is much larger as the } \\
\text { "influence function" is less } \\
\text { known and type c } \\
\text { uncertainty is much larger } \\
\text { as deals do not stay done (as } \\
\text { other parties may intervene) } \\
\text { and type d is larger as who } \\
\text { are the "favored" firms may } \\
\text { change dramatically over } \\
\text { time due to political } \\
\text { instability }\end{array}$ \\
\hline
\end{tabular}

Keep in mind these types of deals environments are not characterizations of

“countries” but rather are firm specific and policy domain specific, interactively (some

firms may have favorable deals in one policy domain but not another). Kaufmann, 
Mastruzzi, and Zavaleta (2003) in Bolivia show large differences in the implementation capability across public sector organizations so firms in some policy domains may face "rules are the rules” while in others face disordered deals. This extends to firm specificity as well as firm may have a closed ordered deal in one domain (say, capture of their industry’s regulatory body) but face open ordered deals in others, say land use, disordered deals in another, say tax collection and face "rules are the rules” in yet another, say environmental regulation. Firms, even in the same activity in the same country do not face some common abstract "policy” or even "environment” rather they form their own positive model specific to each policy domain.

Open Ordered Deals. One possibility, as illustrated in the driver's license example above is a deviation from the formal rules (hiring a facilitator exempts one from the driving exam) but one that is open to all comers and one with a predictable outcome (hiring the facilitator does result in the license). In this case there may be very little policy implementation uncertainty-the deals environment resulting from weak organizational capability for policy implementation takes the form of thwarting the public policy purpose of the regulation (ensuring competent drivers) but does not create uncertainty. That is, while there might be variation (across regions or countries) in how costly or onerous a barrier the deal constitutes to getting a driver's license it need not create much additional uncertainty. One might even argue that the "rules" versus "deals" distinction does not hold as this is just a contrast of "formal rules" with "informal rules" but we prefer the distinction between formal rules and deals when the policy deal is in explicit violation of the formal rule and hence not legally enforceable in principle ${ }^{17}$.

\footnotetext{
17 Some of the literature on "institutions as rules" takes a very broad view of a rule as a pattern of "beliefs norms and practices" and hence view "rules” and implemented formally or informally. However, we
} 
An important distinction for open ordered deals versus other types is often is between deviations in two conceptually distinguishable steps of policy implementation: a “findings" or determination step, in which the state of the world is administratively established, and a policy action step, in which the agent of the state (of the designated organization) takes an action. While conceptually distinct, these steps may be taken by the same person simultaneously (e.g. health inspector inspects the premises and issues a rating), but they may also done by different agents in the same organization (e.g. one agent gives the driving exam and another issues the licenses), or undertaken by separate organizations at distinct times (e.g. a policeman issues a citation, a court adjudicates the claim and issues a fine). Table 2 gives examples from a variety of common functions of the state: tax collection, regulation, and program implementation/service delivery just to emphasize the conceptual distinction between findings and actions. This distinction is important because many deals are not about violating the rules but rather about altering the administratively declared state of the world-irrespective of the factual state of the world--such that application of the rule produces the desired policy action. This tends to produce more ordered deals: once legally granted, even if in violation of the procedures for doing so, the determination is often difficult to revoke.

maintain there is an important difference between "informal institutions" that arise outside of formal rules that may provide quite stable environments for deals between private actors (Greif 2006) and practices, even common widespread practices, that are explicitly forbidden by formal rules between agents of the state and private actors. 


\begin{tabular}{|c|c|c|}
\hline $\begin{array}{l}\text { Notional Policy } \\
\text { mapping }\end{array}$ & $\begin{array}{l}\text { Determination phase, } \\
\text { declaration of administratively } \\
\text { relevant state of the world }\end{array}$ & Action phase \\
\hline \multicolumn{3}{|c|}{ Tax Collection } \\
\hline $\begin{array}{l}\text { Import Duties: } \\
\text { Tariff code from types } \\
\text { of goods to tariff rates }\end{array}$ & $\begin{array}{l}\text { What type of good is it in the } \\
\text { tariff code classification? Is it in } \\
\text { an "exempt" category? What is } \\
\text { the import value? }\end{array}$ & $\begin{array}{l}\text { Apply the specified rate to } \\
\text { the category from the } \\
\text { tariff code and collect } \\
\text { appropriate tax }\end{array}$ \\
\hline $\begin{array}{l}\text { Property Tax } \\
\text { Value of property to } \\
\text { amount owed }\end{array}$ & $\begin{array}{l}\text { What is the taxable value of the } \\
\text { property? Is it exempt? }\end{array}$ & $\begin{array}{l}\text { Collect the tax resulting } \\
\text { from applying rate to } \\
\text { assessed value }\end{array}$ \\
\hline \multicolumn{3}{|c|}{ Regulation } \\
\hline $\begin{array}{l}\text { Urban Zoning/ } \\
\text { Planning Specification } \\
\text { of spatially allowed } \\
\text { types of activities }\end{array}$ & $\begin{array}{l}\text { Is the activity of the designated } \\
\text { type, Residential? Commercial? } \\
\text { Industrial? }\end{array}$ & $\begin{array}{l}\text { Issue zoning certificate for } \\
\text { the designated activity }\end{array}$ \\
\hline $\begin{array}{l}\text { Driver's license } \\
\text { Personal qualifications } \\
\text { to type of license }\end{array}$ & $\begin{array}{l}\text { Does the applicant meet the } \\
\text { specified criteria (e.g. age, } \\
\text { residence, competence) for the } \\
\text { type of license? }\end{array}$ & Issue driver’s license \\
\hline $\begin{array}{l}\text { Allowable Rate of } \\
\text { Return Utility } \\
\text { Regulation } \\
\text { Conditions of firm } \\
\text { providing to allowable } \\
\text { rates/services }\end{array}$ & $\begin{array}{l}\text { What is the value of the installed } \\
\text { capital? }\end{array}$ & $\begin{array}{l}\text { Allow charges sufficient } \\
\text { to generate the stipulated } \\
\text { return on the capital }\end{array}$ \\
\hline \multicolumn{3}{|c|}{ Service Delivery/Program Implementation } \\
\hline $\begin{array}{l}\text { Old Age Pension } \\
\text { From characteristics } \\
\text { (e.g. contributions) to } \\
\text { eligibility and amount }\end{array}$ & $\begin{array}{l}\text { Is the person eligible? What } \\
\text { were their total } \\
\text { contributions/relevant earnings? }\end{array}$ & $\begin{array}{l}\text { Issue a check in the } \\
\text { appropriate amount }\end{array}$ \\
\hline \multicolumn{3}{|c|}{ Contracting for public works/service provision } \\
\hline $\begin{array}{l}\text { Road Construction } \\
\text { From “lowest cost } \\
\text { qualified bid” to contract }\end{array}$ & $\begin{array}{l}\text { Who are the qualified bidders? } \\
\text { Which is the "best" bid on the } \\
\text { specified criteria? }\end{array}$ & $\begin{array}{l}\text { Issue the contract to the } \\
\text { chosen bidder. }\end{array}$ \\
\hline
\end{tabular}

Closed Ordered Deals. The distinction with open ordered deals are deals that are ordered - in that they are roughly predictable both ex ante and ex post-but which are 
"closed" in that they are only available to some firms ${ }^{18}$. In a "closed ordered deals" environment characteristics of the firm may alter the scope of deals available. There may be implicit or explicit "regulatory forbearance" for firms owned by the government, or by members of the President's family, or firms owned by powerful families or business groups or the military, or special deals for some international firms. Fisman (2001) has shown for instance that the stock market value of firms owned by people related to the Indonesian ruler Suharto were substantially higher than otherwise because of their connections to Suharto ${ }^{19}$. In this case there is a different set of available deals for the connected firms as the influence is done "wholesale" rather than "retail." These firms get deals that are closed in that the same deal may not be available to other firms. In fact, as documented in Hellman, Jones and Kaufmann (2000) Seize the State to Seize the Day dominant firms may use their influence over governments not only to improve the policy actions they face but actively worsen the policy and policy actions their competitors face (both formally and informally) ${ }^{20}$ Similarly, Slinko, Yakolev, and Zhuravaskaya (2005) show that politically connected firms receive specific differential treatment that both improves their performance and lowers the performance of other firms in the same region that are not politically connected.

This distinction implies that the "policy environment" varies across firms so that one would expect policy action variability (even conditional on a state of the world) so that

\footnotetext{
${ }^{18}$ Although we had made this open/closed distinction prior to reading North, Wallis and Weingast (2009) our distinction is obviously similar to their distinction between "open access" societies in which something like the same set of rules applies to all actors versus what they term as "natural" states in which there are, explicitly or implicitly, one set of rules for the "elite" and another for others.

${ }^{19}$ A month or so after Suharto was replaced by Megawati a businessman saw Megawati's husband in a restaurant with prominent private sector figures. He said to his lunch companion "I didn't know Megawati's husband was a business man." The response: "He is now."

${ }^{20}$ Again, a process not at all exclusive to developing countries as "raising rival's costs" through regulatory actions that favor incumbent firms (such as imposing the adoption of techniques or standards costly to entrants or licensing procedures) is an integral part of regulatory capture.
} 
the goods of connected firms may clear customs faster, their licenses approved more rapidly, their taxes audited less often, etc. This creates differential policy action uncertainty across different firms as the non-connected firms may face an "open disordered” deals environment, which is not a notion of "dualism” not necessarily between "informal" and "formal" firms but between "favored formal" firms and all others, including non-favored firms in the formal sector ${ }^{21}$.

Disordered Open Deals. Not all "open” deals environments are "ordered" in that the mapping between the influence actions of firms and the policy action outcome are known with reasonable precision up front and the policy action taken ex post of the firm's influence actions will stay done. As Shleifer and Vishny (1993) argue, the distinction between "organized" and "unorganized" corruption can make a difference in its impact. In a disordered deals environment firms feel the need to use deals but still have large residual inter-temporal uncertainty about future policy actions. Bribing an official today may not mean I don't face a different official tomorrow. Or, across policy domains, bribing an official to get a land-use permit may not help getting an operating license or protect me from police extortion or a rapacious tax collector.

Disordered Closed Deals. A “closed” deal environment also may be uncertain, in two dimensions. First, it is inter-temporally uncertain if the underlying power that structures the "order" in the deals is itself inter-temporally uncertain. So, it may well be the only way to do business is to have the President's brother-in-law as a partner but that same connection may prove to be a negative when that President is replaced by another.

\footnotetext{
${ }^{21}$ De Soto's Mystery of Capital describes this as those firms inside a bubble in which they could count on their property rights being protected by the formal apparatus of government and those that cannot. This should not be elided with the notion of access to the "rule of law" or not as the protection of property rights inside the bubble need not be the operation of the "rule of law" open to all but rather a different order.
} 
This isn't to conflate the order with a particular political administration, this varies widely as some closed power structures may persist across political administrations (when "elites" have a common interest) while others may not. This distinction has been made in various ways, identifying regimes that are "patrimonial" or the focus on the lack of constraints on the executive, which combined with inter-temporal uncertainty about regime duration, can create substantial firm level uncertainty, even for those firms inside “closed” deals.

\title{
III) How to interpret firms' aversion to "Policy Uncertainty"
}

\author{
Rules? In a knife fight? No rules. \\ Harvey Logan to Butch Cassidy \\ Butch Cassidy and the Sundance Kid
}

The Enterprise Surveys implemented by the World Bank contains both subjective assessments by firms about the obstacles to their growth, but also quantitative information about how long it takes to get various things done and how much they cost including actions to influence policy implementation, like bribes or gifts or meeting with government officials. Using these data we show six overlapping pieces of evidence that firms complaints of "policy uncertainty" are mainly about policy implementation uncertainty.

First, to show uncertainty we start by showing firm level variability. The Enterprise Surveys have been used to document differences in the investment climate across countries or regions within countries (Dollar, Hallward-Driemeier, and Mengistae 2005) by looking at the averages or central tendency across firms and, at times, the differences in averages across types of firms, such as small versus large. Here we focus 
directly on the variability of the firms' response to the same questions in the same country about how long accomplishing various regulatory tasks take to show that there is indeed enormous variability, which we will then show is related to policy implementation uncertainty. Figure 2 shows the $90^{\text {th }}, 50^{\text {th }}$ and $10^{\text {th }}$ percentiles for the most recent Enterprise Survey data for each Africa country for all countries with more than 30 firm respondents for each question. Figure $2 \mathrm{a}$ shows the distribution of the number of days to get an operating license and Figure $2 \mathrm{~b}$ the number of days for imports to clear customs.

What is striking is that the variation across firms within a country is, in many instances, enormously larger than the differences across countries. Of the 24 countries the country with the lowest median time is Rwanda, at just 1 day and many others report low median times-the median in Ghana is only 4 days. The slowest are Zambia and South Africa at 21 days. Clearly the "typical” firm gets a license much faster in Rwanda or Ghana than Zambia or South Africa. However, 25 percent of firms in Zambia or South Africa report they get their license in 7 days or less while 25 percent of firms in Ghana report it took them 14 days or longer. Taking the $90^{\text {th }}-10^{\text {th }}$ or $75^{\text {th }}-25^{\text {th }}$ percentile spread as a measure of dispersion across firms shows that in all but one country (Rwanda) the $90^{\text {th }}-10^{\text {th }}$ spread is as large as or larger than the maximum range (21 days) across countries. The median $90^{\text {th }}-10^{\text {th }}$ spread in these countries is 46 days and the median $75^{\text {th }}$ $25^{\text {th }}$ spread is 21 days. The implication is that firms that get licenses quickly get them almost instantaneously while firms that get them slowly get them very slowly. The same is true of spreads across firms of the time reported to get goods through customs. The 
median $90^{\text {th }}-10^{\text {th }}$ spread across countries is 14 days, so that firms in the $20^{\text {th }}$ percentile report 1 to 2 days while firms in the $90^{\text {th }}$ percentile typically report two weeks or more ${ }^{22}$.

Figure 2: Variability in policy actions across firms....

\section{2a: Variability in days to get an operating license across firms $\left(90^{\text {th }}-10^{\text {th }}\right.$ percentile difference) within countries}

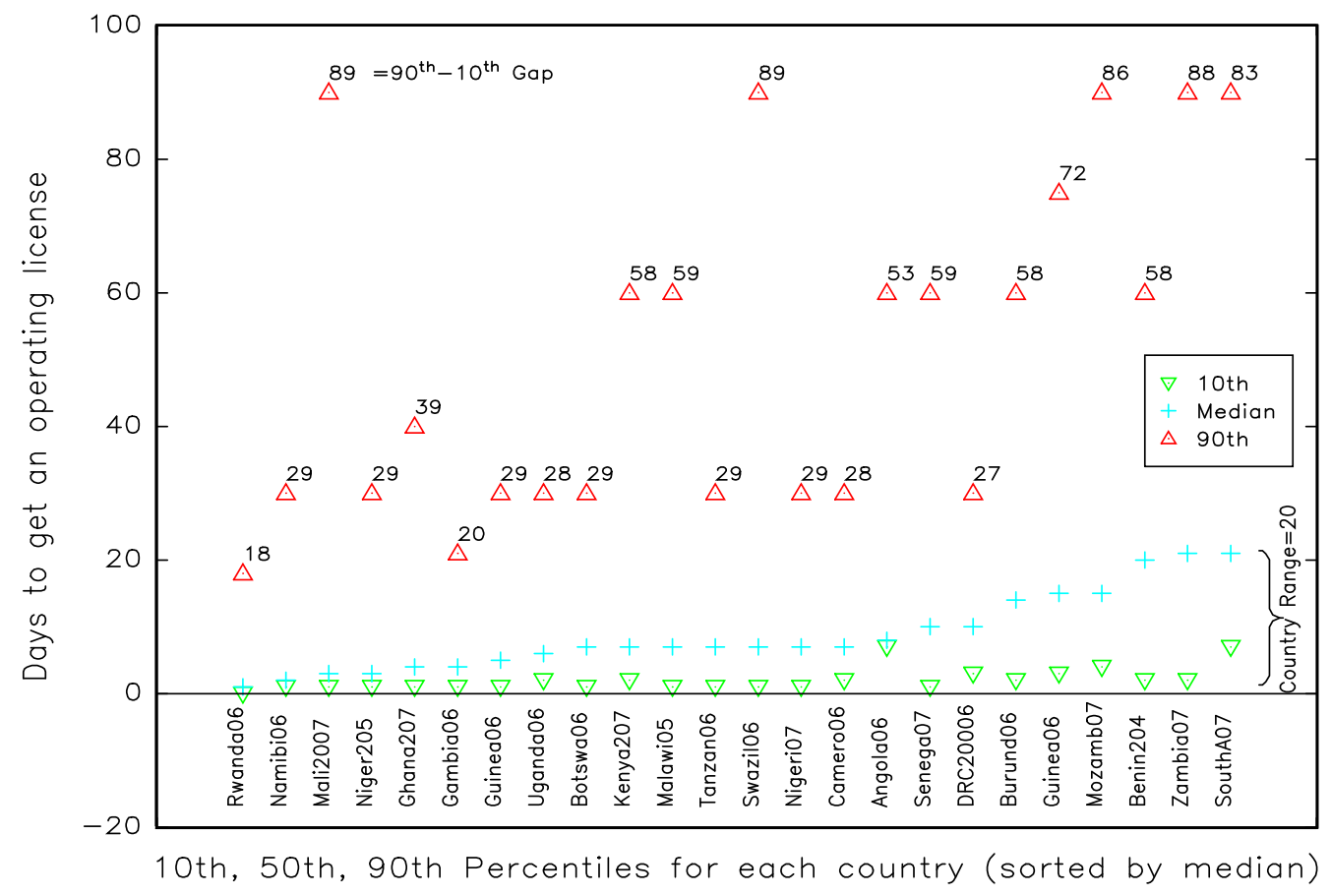

\footnotetext{
${ }^{22}$ Obtaining construction permits is reported by fewer firms so only 12 countries had more than 30 firms reporting times but there again the median $90^{\text {th }}-10^{\text {th }}$ percentile across firms in the same country was 84 days compared the maximum cross country range of 68 days.
} 
2b: Variability in days to clear customs across firms $\left(90^{\text {th }}-10^{\text {th }}\right.$ percentile difference) within countries

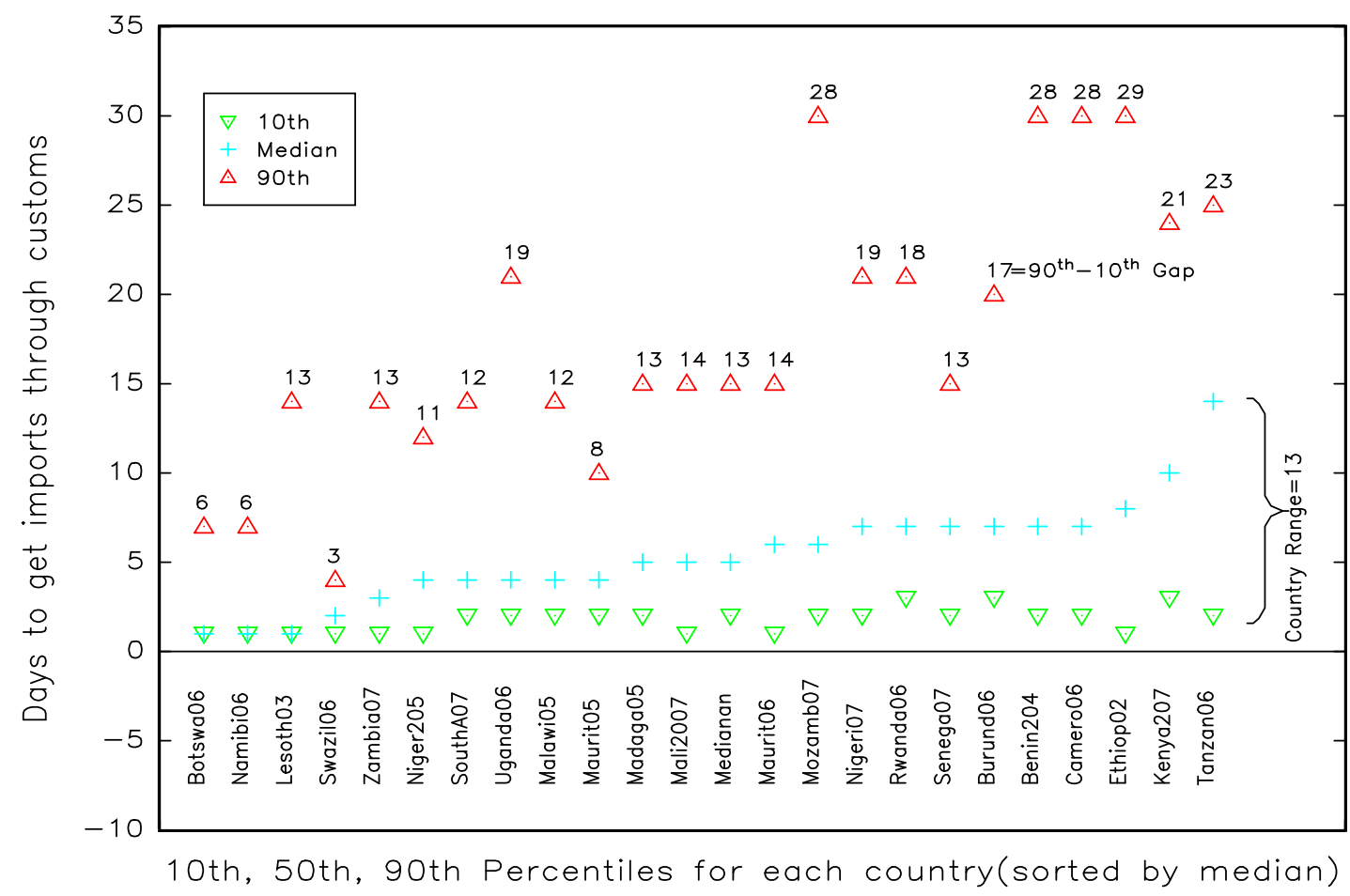

Of course this reported variability is potentially the result of many sources of heterogeneity and hence represents different types of firm uncertainty. One is the possibility of measurement error in the firms' responses. Another is that not all firms are in the same sectors and there may be true "rules are the rules" variability if the rules require different times for implementation (one would expect a construction permit to take longer for a nuclear plant than a restaurant). But there are also other sources of firm level variation from deals. Some of this firm level variability could reflect differences in treatment of favored and disfavored firms by their characteristics (e.g. ownership). As these policy implementation realizations are conditional on firms chosen influence activities, some of the firm level variability could reflect firm's uncertainty about the influence function and some got a good deal and some a bad deal. Alternatively, some of the variability could reflect firms' differential willingness to trade off influence activities 
for delay. Finally, some variability could just reflect randomness in implementation, even after firms’ influence activities.

One piece of evidence that the variability is the result of unpredictable policy implementation is that firms were asked if they believed that implementation of government rules is "consistent and predictable.” Figure 3 shows the association between the fraction of firms who believe implementation is "consistent and predictable." Across the countries, at least 40 percent of firms in Africa report that their positive expectation (PMIP) of policy implementation is that it will have substantial “unpredictable” uncertainty. Moreover, as can be seen in Figure 3 this is reasonably associated with the $90^{\text {th }}-10^{\text {th }}$ percentile gap for days to get an operating license (Figure 3a) and days to clear customs (Figure 3b). For instance, in Mauritius where the intra-firm variability is clearing customs only 8 days around two-thirds of firms believe rules are predictable, whereas in Mozambique where the spread between the $25^{\text {th }}$ and $75^{\text {th }}$ percentile is 28 days only 21 percent of firms agree that the implementation of the rules is predictable. 
Figure 3: Variability in policy actions across firms and beliefs in the "consistency and predictability" of implementation

...3a: $90^{\text {th }}-10^{\text {th }}$ spread in days to get an operating license and fraction of firms reporting implementation is "consistent and predictable"

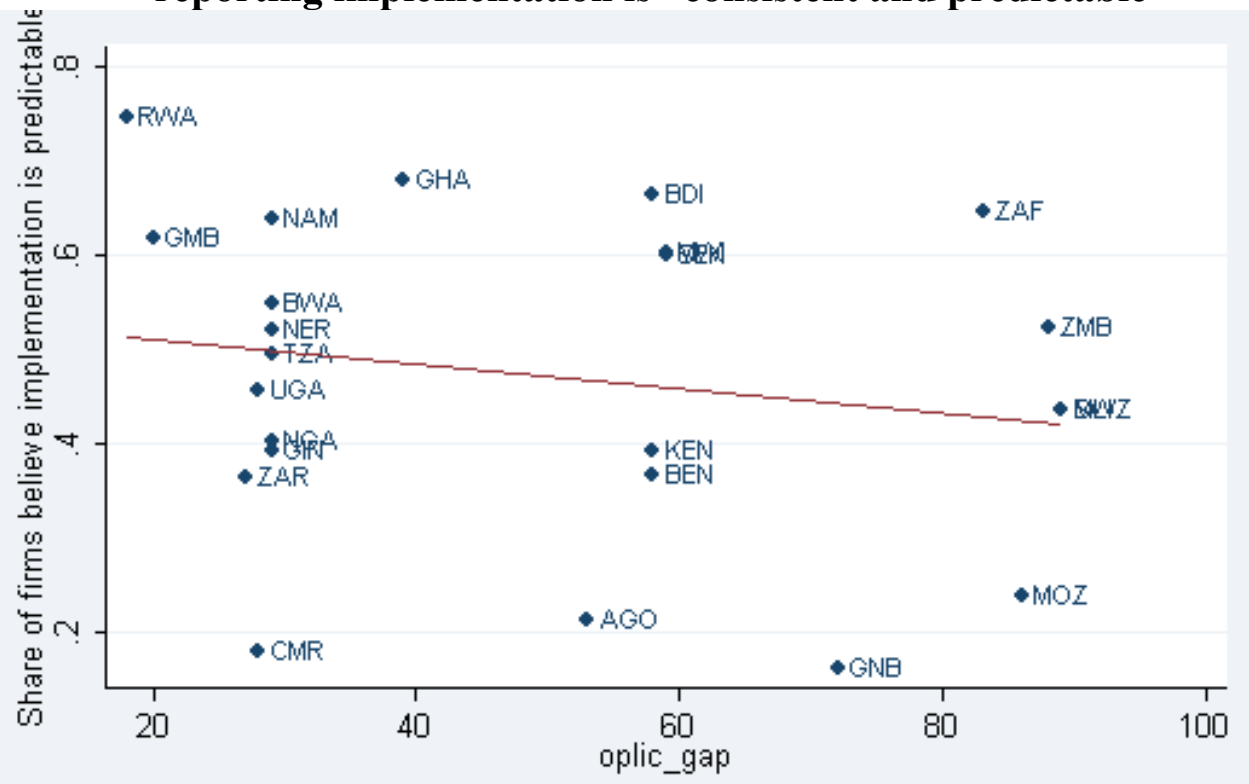

Spread (10-90th percentiles) in Days to Get Operating License

- av_consistD Fitted values

$\ldots .3 \mathrm{~b} 90^{\text {th }}-10^{\text {th }}$ spread in days to clear customs across firms and fraction of firms reporting implementation is "consistent and predictable"

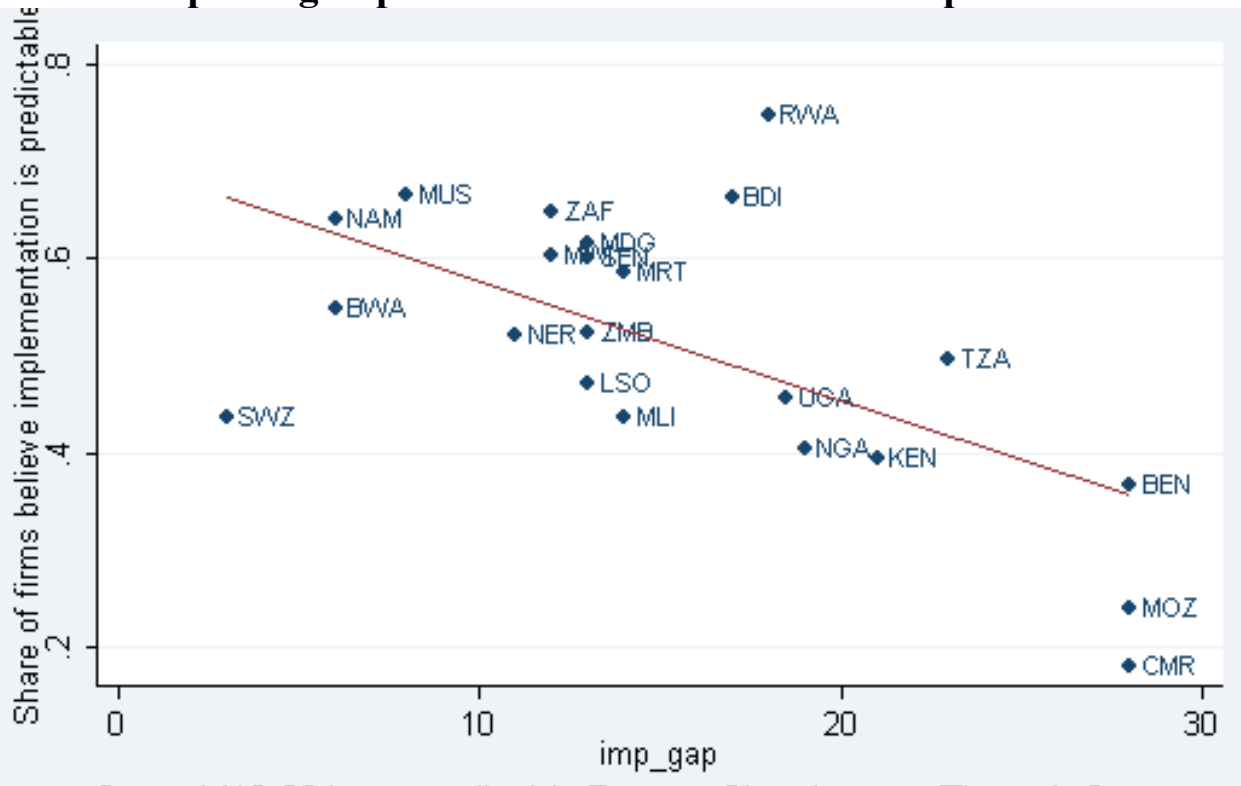

Spread (10-90th percentiles) in Days to Clear Imports Through Customs

- av_consistD Fitted values 
A second piece of evidence that the firm variability is not simply random but is related to firms' perceived policy implementation uncertainty is that there are often differences across firms in whether or not the implementation of rules is "consistent and predictable” consistent with differences in whether firms face ordered versus disordered implementation and how open or closed it is to all firms. Table 4 shows that in Nigeria, which all agree is a weak overall implementation environment, small firms are much more likely to believe that the government is not "consistent and predictable" than are large firms (64 percent versus 39 percent). In Ghana, although firms are much more likely in general to believe implementation is consistent and predictable, capital intensive firms are much more likely to think implementation is consistent and predictable than labor intensive firms (24 versus 39 percent). In the average of all firms in the Africa sample it is the case that small firms are less likely to believe implementation is consistent and predictable than large firms (54 versus 46 percent). While all evidence is subject to multiple interpretations, these results are consistent with differences in the policy implementation even when firms facing the same de jure policy. ${ }^{23}$ In an environment of closed deals, firms would be more likely become large or capital intensive if they have preferential access to deals to accommodate the uncertainty of policy implementation, hence for those firms implementation is consistent and predictable.

\footnotetext{
${ }^{23}$ It is true that in some countries the de jure rules may vary by size. For example, large firms may need to provide financial statements in calculating tax payments, while small firms may be assessed a 'presumptive tax'. This of course leaves more room for arbitrariness - and something over which to make a deal.
} 


\begin{tabular}{|c|c|c|c|c|}
\hline Туре & Nigeria & Uganda & Ghana & $\begin{array}{c}\text { Unweighted } \\
\text { average of } \\
\text { all firms } \\
\end{array}$ \\
\hline Small (Employees<6) & $63.9 \%$ & $43.4 \%$ & $32.2 \%$ & $53.9 \%$ \\
\hline Medium(6<employees $<21)$ & $60.2 \%$ & $47.6 \%$ & $34.1 \%$ & $50.6 \%$ \\
\hline Large (Employees>21) & $38.6 \%$ & $41.5 \%$ & $31.3 \%$ & $46.4 \%$ \\
\hline Labor Intensive & $59.5 \%$ & $51.4 \%$ & $39.0 \%$ & $51.9 \%$ \\
\hline Capital Intensive & $56.2 \%$ & $40.1 \%$ & $24.6 \%$ & $50.3 \%$ \\
\hline Services & $61.2 \%$ & $41.7 \%$ & $30.7 \%$ & $52.6 \%$ \\
\hline Capital City & $65.9 \%$ & $46.2 \%$ & $28.7 \%$ & $53.2 \%$ \\
\hline Medium/large & $55.5 \%$ & $42.1 \%$ & $40.9 \%$ & $49.4 \%$ \\
\hline Small city & $75.1 \%$ & $35.5 \%$ & $34.1 \%$ & $60.5 \%$ \\
\hline Total & $59.7 \%$ & $44.4 \%$ & $32.1 \%$ & $51.90 \%$ \\
\hline
\end{tabular}

A third piece of evidence that policy implementation is uncertain is that firms engage in actions aimed at influencing policy implementation, including actions, such as paying bribes, that are not a part of the de jure policy implementation or the notional policy mapping. The extent of policy influence activity firms report varies across countries and across firms within a country. Table 4 shows the fraction of management time spent with government officials, the fraction of firms who report paying bribes and the proportion of revenue paid as bribes for those who do pay bribes. Obviously if the rules were followed irrespective of whether a bribe was paid the fraction paying bribes would be small, but in half of the countries half of the firms report paying bribes. The fraction reporting paying bribes varies from ubiquitous, over 80 percent, in Burkina Faso, DRC, Guinea to 20 percent or less in Rwanda and South Africa. 


\begin{tabular}{|c|c|c|c|c|c|c|}
\hline \multirow[t]{3}{*}{$\begin{array}{l}\text { Country and year of } \\
\text { survey }\end{array}$} & \multicolumn{2}{|c|}{$\begin{array}{l}\text { Percent of management } \\
\text { time spent dealing with } \\
\text { officials }\end{array}$} & \multicolumn{4}{|c|}{ Bribes } \\
\hline & \multirow[t]{2}{*}{ Average } & \multirow{2}{*}{$\begin{array}{l}\text { Standard } \\
\text { Dev. }\end{array}$} & \multirow{2}{*}{$\begin{array}{l}\text { Percent } \\
\text { paying }\end{array}$} & \multicolumn{3}{|c|}{ Amount as a percent of sales } \\
\hline & & & & $\begin{array}{c}\text { Average } \\
\text { of those } \\
\text { paying } \\
\text { a bribe }\end{array}$ & $\begin{array}{l}\text { Std dev } \\
\text { of those } \\
\text { paying }\end{array}$ & $\begin{array}{c}\text { Std dev } \\
\text { of all } \\
\text { firms }\end{array}$ \\
\hline BurkinaFaso2006 & 11.01 & 15.30 & $97.7 \%$ & 8.23 & 8.73 & 8.59 \\
\hline Guinea2006 & 3.74 & 6.84 & $92.4 \%$ & 5.34 & 7.98 & 7.80 \\
\hline Cameroon2006 & 14.06 & 15.42 & $91.6 \%$ & 3.88 & 8.87 & 8.44 \\
\hline Mauritania2006 & 6.10 & 12.70 & $90.4 \%$ & 4.83 & 7.58 & 7.31 \\
\hline DRC2006 & 6.83 & 10.63 & $87.1 \%$ & 5.13 & 6.67 & 6.45 \\
\hline Niger2005 & 13.20 & 19.39 & $86.2 \%$ & 6.53 & 6.92 & 6.56 \\
\hline GuineaBissau2006 & 3.20 & 5.98 & $75.5 \%$ & 4.66 & 5.38 & 4.98 \\
\hline Kenya2007 & 6.84 & 7.63 & $75.0 \%$ & 3.82 & 4.46 & 4.20 \\
\hline Burundi2006 & 5.90 & 9.14 & $67.2 \%$ & 8.89 & 7.01 & 7.07 \\
\hline Gambia2006 & 7.52 & 12.28 & $64.3 \%$ & 6.62 & 8.49 & 7.15 \\
\hline Uganda2006 & 5.56 & 7.34 & $63.7 \%$ & 6.20 & 6.80 & 6.08 \\
\hline Benin2004 & 8.29 & 14.39 & $57.6 \%$ & 8.65 & 7.29 & 6.99 \\
\hline Tanzania2006 & 4.89 & 7.89 & $55.7 \%$ & 5.83 & 6.86 & 5.87 \\
\hline Swaziland2006 & 4.66 & 7.08 & $55.3 \%$ & 3.57 & 5.69 & 4.51 \\
\hline Angola2006 & 7.94 & 8.75 & $51.4 \%$ & 6.21 & 7.43 & 6.04 \\
\hline Nigeria2007 & 6.63 & 9.43 & $46.9 \%$ & 3.94 & 5.19 & 4.06 \\
\hline Botswana2006 & 5.42 & 9.10 & $45.7 \%$ & 3.31 & 7.00 & 4.55 \\
\hline CapeVerde2006 & 14.06 & 18.55 & $33.3 \%$ & 2.17 & 2.32 & 0.87 \\
\hline Ghana2007 & 3.69 & 6.27 & $33.3 \%$ & 5.90 & 7.12 & 4.96 \\
\hline Lesotho2003 & 22.11 & 24.77 & $33.3 \%$ & 1.79 & 3.06 & 1.93 \\
\hline Malawi2005 & 7.89 & 13.35 & $33.3 \%$ & 6.73 & 8.43 & 5.78 \\
\hline Rwanda2006 & 4.99 & 9.43 & $29.1 \%$ & 7.34 & 10.59 & 6.52 \\
\hline Mali2007 & 2.43 & 3.61 & $28.1 \%$ & 4.07 & 5.06 & 3.24 \\
\hline Namibia2006 & 4.12 & 7.55 & $25.3 \%$ & 4.96 & 7.63 & 3.65 \\
\hline Senegal2007 & 3.68 & 6.81 & $24.8 \%$ & 6.30 & 8.19 & 4.90 \\
\hline Madagascar2005 & 22.19 & 23.00 & $24.2 \%$ & 6.18 & 9.75 & 5.45 \\
\hline Zambia2007 & 5.56 & 8.32 & $20.1 \%$ & 5.95 & 8.01 & 4.30 \\
\hline SouthAfrica2007 & 6.46 & 7.49 & $17.5 \%$ & 4.97 & 9.07 & 4.23 \\
\hline Mauritius2005 & 11.28 & 14.94 & $17.1 \%$ & 3.31 & 3.68 & 1.95 \\
\hline Mozambique2007 & 4.05 & 6.50 & $16.8 \%$ & 8.71 & 9.07 & 4.93 \\
\hline Cross Country median & 6.28 & 9.12 & $49 \%$ & 5.58 & 7.21 & 5.22 \\
\hline
\end{tabular}


Table 5 examines the variation across firms of the types of actions that could be undertaken to influence policy implementation outcomes by examining the correlates of (admitting to) deal making, measured as 'bribes paid to 'get things done’. To investigate if bribe paying is associated with policy implementation uncertainty we need a measure of the policy uncertainty a firm faces. We proxy this by using the both the observed levels and variability of similarly situated firms. We do this by forming summary statistics of the level and variability of observations in the same "cell" (country, city, sector, size) as any given firm. ${ }^{24}$ For instance, firms are asked what percent of management time is spent with government officials. We can calculate not only how much time firm $i$ spent with government officials, but also the average of all other firms in the same cell as firm $i$ and the standard deviation of those firms. This captures the differences across firms. We do the same thing for whether firms consider policy implementation is "consistent and predictable"; how much firms disagree with the extent of consistency and predictability there is in policy implementation might actually be a good proxy for implementation uncertainty overall.

Table 5 shows that including the cell standard deviations, the average levels of management time and consistency are not significant except in the case of the size of bribes paid. While these associations are obviously subject to a variety of interpretations, it is striking that whether a firm pays a bribe is associated with how much disagreement there is among firms in the firm's same location, sector, and size about whether regulations are "consistent and predictable." Similarly, paying a bribe is not associated

\footnotetext{
${ }^{24}$ We exclude cells without at least 6 or more responses. We also ran robustness checks only using cells with 30 or more responses and the results were similar.
} 
with the average time similar firms spend with officials but with the differences across

firms in the same cell in the amount of time spent. ${ }^{25}$

\footnotetext{
${ }^{25}$ Variation in the "cell” of firms in the assessment of consistency does not necessarily imply ex ante uncertainty; some firms, for instance, the politically well connected, could know in advance the differential treatment they would receive. The point is that deals involving bribes appear more likely not just when firms think there is less consistency but where there is a difference across firms with respect to the extent of consistency, i.e. when some firms report consistency and some do not, which means firms are uncertain and this condition appears to be more favorable to try to influence policy actions via firm specific deals.
} 
Table 5: Is paying bribes associated with policy implementation uncertainty? Dependent variable: Firms reports paying a bribe, Probit regressions

\begin{tabular}{|c|c|c|c|}
\hline & (1) & $(2)$ & (3) \\
\hline & -0.147 & & \\
\hline Average: Share report consistent implementation & $(0.101)$ & & \\
\hline & $0.125^{* *}$ & & \\
\hline STD: Reported consistency in implementation & $(0.057)$ & & \\
\hline Average: Management time & & -0.005 & \\
\hline & & $(0.006)$ & \\
\hline STD: Management time & & $0.012 * *$ & \\
\hline & & $(0.005)$ & \\
\hline Average: Size bribe paid by others & & & $0.088 * * *$ \\
\hline & & & $(0.011)$ \\
\hline STD: Size bribe paid by others & & & $-0.027 * * *$ \\
\hline & & & $(0.007)$ \\
\hline Firm Characteris & & & \\
\hline Age_middle & $-0.031^{*}$ & $-0.034^{* *}$ & $-0.033 * *$ \\
\hline & $(0.016)$ & $(0.017)$ & $(0.017)$ \\
\hline Age_old & $-0.039 * *$ & $-0.042 * *$ & -0.032 \\
\hline & $(0.020)$ & $(0.020)$ & $(0.021)$ \\
\hline Small & 0.026 & 0.022 & $0.030^{*}$ \\
\hline & $(0.016)$ & (0.017) & (0.017) \\
\hline Medium & -0.026 & -0.036 & 0.010 \\
\hline & $(0.026)$ & $(0.027)$ & $(0.034)$ \\
\hline Large & 0.034 & 0.032 & 0.052 \\
\hline & $(0.036)$ & $(0.036)$ & $(0.044)$ \\
\hline Very large & 0.005 & 0.004 & -0.002 \\
\hline & $(0.053)$ & $(0.054)$ & $(0.065)$ \\
\hline Foreign & -0.003 & -0.006 & -0.016 \\
\hline & $(0.017)$ & $(0.017)$ & $(0.018)$ \\
\hline Government & $-0.095^{* *}$ & $-0.088 * *$ & $-0.091 *$ \\
\hline & $(0.040)$ & $(0.042)$ & $(0.052)$ \\
\hline Large city & $-0.083 * * *$ & $-0.102 * * *$ & $-0.040 *$ \\
\hline & $(0.023)$ & $(0.026)$ & $(0.021)$ \\
\hline Small city & $-0.092 * *$ & $-0.075^{*}$ & 0.024 \\
\hline & $(0.045)$ & $(0.038)$ & $(0.038)$ \\
\hline Observations & 12393 & 12088 & 10652 \\
\hline $\mathrm{Chi}^{2}$ & 3156 & 2800 & 2104 \\
\hline Prob $>\mathrm{Chi}^{2}$ & 0.00 & 0.00 & 0.00 \\
\hline Pseudo R2 & 0.20 & 0.20 & 0.17 \\
\hline
\end{tabular}

Robust standard errors in parentheses, ${ }^{* * *} p<0.01, * * p<0.05, * p<0.1$

Cells defined by location-sector-size; country and sector dummies included 
One difficulty in parsing the evidence about why firms reporting disliking "policy uncertainty" is disentangling whether it is the fact of deviation per se or whether it is the uncertainty created by “disordered” deals or whether firms are expressing resentment at the uneven access to deals. An interesting finding comes from several of the surveys, which asked a question meant to elicit whether the practice of bribery, if it was regular and predictable, in and of itself constituted an obstacle to business. The firms were given the following vignette:

Musyoka needs to renew a small business license from a local government office each year. Bribes are welcomed. Musyoka usually includes an additional bribe with his applications. When Musyoka had not included bribes, his application was sometimes lost or there were long delays such that the firm had to re-file.

Firms were then asked "Does corruption represent an obstacle to the operation and growth for Musyoka's business?”

\begin{tabular}{|l|c|c|c|c|}
\hline \multicolumn{6}{|l|}{ Table 6: Are predictable bribes considered an obstacle? } \\
\hline & Zambia & Mozambique & Mali & Nigeria $^{\mathrm{a}}$ \\
\hline No obstacle & 42.5 & 32.31 & 32.31 & 3.15 \\
\hline Minor & 23.33 & 22.31 & 22.31 & 4.86 \\
\hline Moderate & 24.17 & 23.08 & 23.08 & 11.9 \\
\hline Major & 10 & 18.46 & 18.46 & 42.14 \\
\hline Severe & 0 & 3.85 & 3.85 & 37.96 \\
\hline N & 120 & 130 & 130 & $(1800)$ \\
\hline Sour &
\end{tabular}

Source: Author's calculations using Enterprise Survey extension modules

a) In Nigeria, the question was posed after a series of questions asking about corruption, while in the other 3 countries it was part of extension module looking at issues of gender and the prior experience of the entrepreneur.

Consistently more than half of firms in the three countries in which this was asked in a specialized module about entrepreneur experience regarded this as either no or a minor obstacle to business (Nigeria’s results are quite different but this may be the result of “priming” as it was asked in a module about corruption and hence following a larger 
number of questions about corruption). This suggests that firms are distinguishing between "having to pay bribes" per se which in an open ordered deal environment creates a predictable "tax" and policy uncertainty.

Another piece of evidence supports this conclusion. Firms in Cote d'Ivoire, Kenya, Nigeria and Senegal survey responded to whether 'policy uncertainty' was related to concerns about how existing laws and regulations would be applied to them as opposed to intertemporal changes in the laws themselves. Just over 60 percent agreed it was a moderate to severe constraint (similar to the rate given in figure 1). But even more tellingly, firms who report "knowing a bribe will get something done" is not a constraint, were less likely to see uncertainty in implementation as a constraint.

\section{Table 6b:}

\section{Concern about how formal policies will be applied in practice is widespread -- but less so if you see deals as not constraining}

$\begin{array}{llcc} & & \begin{array}{c}\text { Of firms who rank 'knowing a bribe will } \\ \text { get something done' is not a constraint }\end{array} \\ \text { How large a constraint to the operation } & \text { No/Minor constraint } & 39.5 \% & 52.3 \% \\ \text { of your business is "uncertainty about } & \text { Moderate constraint } & 28.3 \% & 26.6 \% \\ \text { how official, formal policies will actually } & \text { Major/Severe } & 32.2 \% & 21.1 \% \\ \text { be applied to my business in practice"? } & \text { Total } & 494 & 104 \\ \text { Supplemental survey of firms in Cote d'Ivoire, Kenya, Nigeria and Senegal } & & \end{array}$

\section{Impact of Deals}

As a final step, we turn to examine the impact of uncertainty and the extent of deals on firm behavior. We look at firm employment decisions and employment growth over a three year time period. The focus is not whether or not a particular firm benefits from participating in a deal, but rather the effect of the 'deals environment' on firm 
growth. ${ }^{26}$ Does the prevalence of deals affect firm growth? Does the orderliness of such deals affect firm growth? This is a new question as while many studies have examined the impacts of various dimensions of the policy environment on firm performance they have focused on the average not the uncertainty. A very recent exception is Sequira and Djankov (2010) who, in a detailed study of ports in Southern Africa find that firms will ship to a much more distant port in order to avoid corruption. Their estimates suggest that firms will incur additional shipping costs that are eight times the average bribe paid, suggesting a very large willingness to pay to avoid the uncertainty induced by (coercive) bribes.

To measure the 'deals environment', we again use the location-sector-size cells of the firms. The regressions include both a measure of the average level of the deals indicator and the standard deviation of that indicator within the cell. To the extent there is greater variability within the cell, this is an indication of the disorderliness of the deals - not everyone is able to get the same deal on the same terms. This variation could also be an indicator of uncertainty about whether the deal struck will in fact be honored. If uncertainty is the underlying concern, we would expect the results on the variation measures to be particularly strong.

The dataset includes information on employment at the time of the survey and three years prior to the survey. In calculating employment growth, we follow Haltiwanger's (2009) approach of using the difference divided by the average. This gives

\footnotetext{
${ }^{26}$ Firm level regressions would also raise concerns about possibility endogeneity - whether expanding firms attract the attention of officials and become targets for officials seeking additional payments. Using location-sector-size averages has been used as a technique to address this concern (Dollar et al 2006, Aterido et al. forthcoming). Here, our interest is different, how the averages and extent of variation themselves affect firms' decisions.
} 
a value that is between plus and minus two and minimizes the role of large outliers that can be present, particularly for smaller firms.

Again, a number of firm characteristics are controlled for, including the average size of the firm over the time period, the age of the firm, its ownership (foreign-domestic, state-private), its sector, and location within the country. The average size of the firm is used rather than the initial size to minimize the effects of transitory changes in employment (Haltiwanger 2009). Country dummies are included to absorb country characteristics, so the variation is between firms within a country.

Another question regards the appropriate size to use in constructing these averages. Most of the questions were made in reference to conditions at the time of the survey, for which current size might be appropriate. However, if firms' size has varied, the responses may better be reflections of the experience of firms like what they had been over a longer period. We opted for using average size. This has the added advantage that it is not necessary to rematch firms to the measured location-sector-size indicators, which would be necessary if firms changed size categories such their responses on deals indicators would be used for, say, large firms, but the conditions they faced at the outset were those of small firms. ${ }^{27}$

$$
\begin{aligned}
Y_{i}=\alpha+\beta \text { Average_Deal_indicator }_{l s z}+\beta S \text { dd_Deal_indicator }_{l s z}+\beta a g e_{i} \\
+\beta \text { size }_{i t-1}+\beta \text { foreign }_{i}+\beta \text { governemnt }_{i}+D_{\text {sector }}+D_{\text {country }}+\varepsilon_{i}
\end{aligned}
$$

Our two principle measures of 'deals' are used: overall management time with officials and the size of bribe payments made to 'get things done.' Standard errors are then clustered by cell.

\footnotetext{
${ }^{27}$ An alternative would be to exclude size as one of the dimensions in constructing cells; the results are very similar although the significance levels are somewhat lower.
} 


\section{Table 7: Prevalence of uncertain deals discourages employment growth}

Dependent variable: 3 year growth rate of permanent employees

\begin{tabular}{|c|c|c|}
\hline & (1) & $(2)$ \\
\hline $\begin{array}{l}\text { Cell average meeting } \\
\text { time with officials }\end{array}$ & $\begin{array}{c}0.014^{* * *} \\
(0.003)\end{array}$ & \\
\hline $\begin{array}{l}\text { Cell Std. Dev. meeting } \\
\text { time with officials }\end{array}$ & $\begin{array}{c}-0.007^{* *} \\
(0.003)\end{array}$ & \\
\hline $\begin{array}{l}\text { Cell average pays } \\
\text { bribes }\end{array}$ & & $\begin{array}{c}0.006 \\
(0.008)\end{array}$ \\
\hline $\begin{array}{l}\text { Cell Std. Dev. pays } \\
\text { bribes }\end{array}$ & & $\begin{array}{l}-0.010 * \\
(0.006)\end{array}$ \\
\hline Age: medium & $\begin{array}{c}-0.078 * * * \\
(0.012)\end{array}$ & $\begin{array}{c}-0.074 * * * \\
(0.013)\end{array}$ \\
\hline Age: old & $\begin{array}{c}-0.167^{* * *} \\
(0.014)\end{array}$ & $\begin{array}{c}-0.161^{* * *} \\
(0.016)\end{array}$ \\
\hline Medium & $\begin{array}{c}-0.027^{* *} \\
(0.011)\end{array}$ & $\begin{array}{c}-0.032 * * * \\
(0.012)\end{array}$ \\
\hline Large & $\begin{array}{c}-0.065^{* * *} \\
(0.016)\end{array}$ & $\begin{array}{c}-0.070 * * * \\
(0.018)\end{array}$ \\
\hline Very large & $\begin{array}{c}-0.099 * * * \\
(0.021)\end{array}$ & $\begin{array}{c}-0.147^{* * *} \\
(0.028)\end{array}$ \\
\hline Foreign & $\begin{array}{c}0.012 \\
(0.012)\end{array}$ & $\begin{array}{c}0.006 \\
(0.013)\end{array}$ \\
\hline Government & $\begin{array}{c}-0.081^{* * *} \\
(0.020)\end{array}$ & $\begin{array}{c}-0.094^{* * *} \\
(0.029)\end{array}$ \\
\hline Large city & $\begin{array}{l}-0.005 \\
(0.015)\end{array}$ & $\begin{array}{c}0.001 \\
(0.022)\end{array}$ \\
\hline Small city & $\begin{array}{c}0.004 \\
(0.035)\end{array}$ & $\begin{array}{c}0.022 \\
(0.036)\end{array}$ \\
\hline Constant & $\begin{array}{c}0.116 \\
(0.107)\end{array}$ & $\begin{array}{c}0.305^{* * *} \\
(0.042)\end{array}$ \\
\hline $\begin{array}{l}\text { Country, sector } \\
\text { dummies }\end{array}$ & Yes & Yes \\
\hline Observations & 13097 & 10419 \\
\hline R-squared & 0.077 & 0.066 \\
\hline
\end{tabular}

Robust standard errors in parentheses

$* * * \mathrm{p}<0.01, * * \mathrm{p}<0.05, * \mathrm{p}<0.1$

The first result is that spending time with officials is indeed associated with better

firm outcomes. In areas where firms are able to make deals, growth is higher. To the 
extent the time represents efforts to make deals with officials, on average, it appears to be worth the effort. However, the inclusion of the standard deviation is also significant and negative. While securing a deal may be advantageous, to the extent there is uncertainty regarding what is required to secure the deal, the benefits are reduced.

The average size of the bribe is not associated with higher growth. However, the standard deviation of bribes paid is. Greater variation in the size of bribes paid in a location-sector-size cell is associated with lower employment growth. Again, this would be consistent with greater uncertainty about whether the deal, once struck, will actually stick.

As a second approach to examine the issue of variability in deal making, we use a difference-in-difference methodology. The approach tests whether the degree of openness and orderliness of the system of deals matters, whether deals can be had by anyone willing to pay, or whether the system is largely closed to all but those with the right (political) connections. If the system is relatively open, the average level of bribe may be high or low, but there should be relatively little variation in the size of bribes paid or in the time managers spend with officials. However, if the system is less open, the variation in bribes paid or the time spent with officials working out deals or seeking compliance with regulations will likely be higher. If only some firms are benefitting from the deals, the greater variation in bribes and/or management time should be associated with relatively larger gaps in opportunities between the two groups.

As a first step we need to construct a measure of the extent to which sectors vary in the degree to which they interact with officials. For firms in sectors that have a higher underlying rate of interaction, the relative openness of making deals is likely to matter 
more. To construct a measure of a sector's intensity of interactions with officials, we use the time spent in inspections, using Germany as the benchmark. Of all the countries that have conducted an ES, it is the one whose measures of rule of law, control of corruption and government effectiveness are strongest. To measure the orderliness of deals in a location, we use two measures: the variation in the size of bribes paid and the variation in the time managers spend with officials in that location.

In determining firms that are more or less likely to have access to orderly deals, information on connections to officials would be desirable, but unfortunately is not available to us. Rather, we use two proxies: size and age. Larger firms and older firms are more likely to have developed close relationships with officials and to benefit from the existing system of deals than smaller firms or newer firms still trying to get established. Several papers have found that smaller firms are more likely to be adversely affected by red tape and corruption (Aterido et al. forthcoming; Beck et al.2005). It is not that small firms or young firms don’t try to get a deal - it is that the terms of the deal and the security of the deal are likely to be more uncertain.

Thus the specification is the following:

$$
\begin{aligned}
y_{l, s}=\alpha+D_{l} & +D_{s}+\beta(\text { Orderliness of Deals } \\
& \left.* \text { Intensity of Government Interactions }_{s}\right)+\varepsilon_{l s}
\end{aligned}
$$

where $\mathrm{y}_{\mathrm{ls}}$ is the gap in growth rates between large and small firms in a given sectorlocation cell. Thus the regressions are testing whether the gap between large and small firms performance is relatively larger in those sectors that would have more interactions with officials and where deals are less open (i.e. greater variability in the bribe payments made and the time spent with officials.). 
As table 8 shows, the gap between large and small firms' growth is relatively

higher in sectors with more interactions with officials and in locations where deals are less orderly. This is particularly true when looking at firms by size. And the effects are more significant for bribes paid than for management time spent with officials.

Table 8: Growth outcomes are relatively more disparate when disordered deals are prevalent, particularly in sectors where more interactions with officials are needed

Difference-in-difference at the location-sector cell level

\begin{tabular}{|c|c|c|c|c|}
\hline \multirow[t]{2}{*}{ Dependent variable: } & \multicolumn{2}{|c|}{$\begin{array}{l}\text { Gap in growth of large } \\
\text { versus small firms }\end{array}$} & \multicolumn{2}{|c|}{$\begin{array}{l}\text { Gap in growth of old } \\
\text { versus young firms }\end{array}$} \\
\hline & $(1)$ & $(2)$ & (3) & $(4)$ \\
\hline Std_Bribes location * Intensity of Govt Interactions $_{\text {sector }}$ & $\begin{array}{l}0.0133^{\star *} \\
(0.0066)\end{array}$ & & $\begin{array}{l}0.0065 \\
(.0074)\end{array}$ & \\
\hline Std Management Time Iocation $^{*}$ Intensity of Govt Interactions & sector & $\begin{array}{l}0.0053^{*} \\
(0.0029)\end{array}$ & & $\begin{array}{l}0.0047 \\
(.0036)\end{array}$ \\
\hline Location dummies & Yes & Yes & Yes & Yes \\
\hline Sector dummies & Yes & Yes & Yes & Yes \\
\hline $\mathrm{R}^{2}$ & 0.33 & 0.31 & 0.24 & 0.28 \\
\hline $\mathrm{N}$ & 260 & 260 & 285 & 285 \\
\hline
\end{tabular}

Prevalence of disordered deals: i) std dev. of bribes paid in a location (metropolitan areas within countries)

ii) standard deviation of management time spent with officials in a location

Sectors are ranked by their 'intensity of interactions with officials', using Germany as the benchmark Robust standard errors are reported; * ${ }^{* *}$ significant at the 10 and 5 percent levels

Overall, these results underscore that just looking at the average level of deals does not capture the story and that uncertainty about the policy implementation environment is itself an important dimension affecting firms’ behavior. 


\section{V) “Send Lawyers, Guns and Money": Doing Business with Deals}

I was gambling in Havana, I took a little risk, Send Lawyers, Guns, and Money Dad, get me out of this

Warren Zevon

Most of the self-reported obstacles to their own firms’ growth have both been recognized in the macroeconomic literature as inhibitors of growth and have had clear programmatic responses. While we cannot do full justice to the complex topics of how to relate policy implementation uncertainty to economic growth and programmatic responses, in this final section we hoped to at least point in some potentially promising directions.

\section{V.A) Policy implementation uncertainty and growth}

The Hausmann, Rodrik, Velasco (2004) “growth diagnostics” framework starts heuristically from the firm level first order condition for investment (marginal benefits versus marginal costs) to develop a diagnostic tree to identify the contextually most “binding” constraints. Figure 4 (Hausmann, Klinger, Wagner 2008) shows a simple version of the growth diagnostic tree, in which the correspondence between a growth framework and the firm's complaints about obstacles to growth is easily seen: "high cost of finance” to firms' complaints of "access to finance”; "bad infrastructure” to firms identification of "electricity” or "transport” or "telecoms"; "low human capital” to firms' “skills availability” as a constraint). One major branch of the growth diagnostic is “appropriability,” that, although investments would be productive, they would not be reliably profitable to individual forms because of "low appropriability” from either market failures (e.g. informational externalities, too little "self discovery” (Hausmann 
and Rodrik (2002)) or coordination issues) or government failures. Government failures can be macroeconomic risks, which are identified by firms as "macroeconomic instability.” But government failures also play out in microeconomic risks, from either government agents themselves or from other private agents with unreliable contracting. Our interpretation is that firm complaints of "policy uncertainty" reflect concerns that policy implementation uncertainty creates risks to the appropriability of the gains from firm level investment or innovation ${ }^{28}$.

We argue that a number of the firm reported obstacles in Figure 1 are related to appropriability risks created by policy implementation uncertainty. In addition to “economic and regulatory policy uncertainty” firms identify not just "policy” variables like the tax rate but also tax administration. Firms commonly identify customs clearance as an obstacle, which is arguably more an implementation than a policy issue. Firms" expressed concerns with "licenses" and "access to land" combine both the policy (is it de jure difficult) but also the de facto concerns about implementation. We believe the broader lens of policy implementation uncertainty also provides a lens into complaints about corruption, both in that it can be disordered and it can create obstacles to firms when corruption is "closed" and is used to close off market competition.

${ }^{28}$ Bigsten and Soderbom (2005) review the research based on a first round of firm surveys in Africa and concluded the uncertainty, paired with irreversibility, explains low investment in African firms not low productivity. 


\section{Figure 4: Growth diagnostic decision tree}

Problem: Low levels of private investment and entrepreneurship

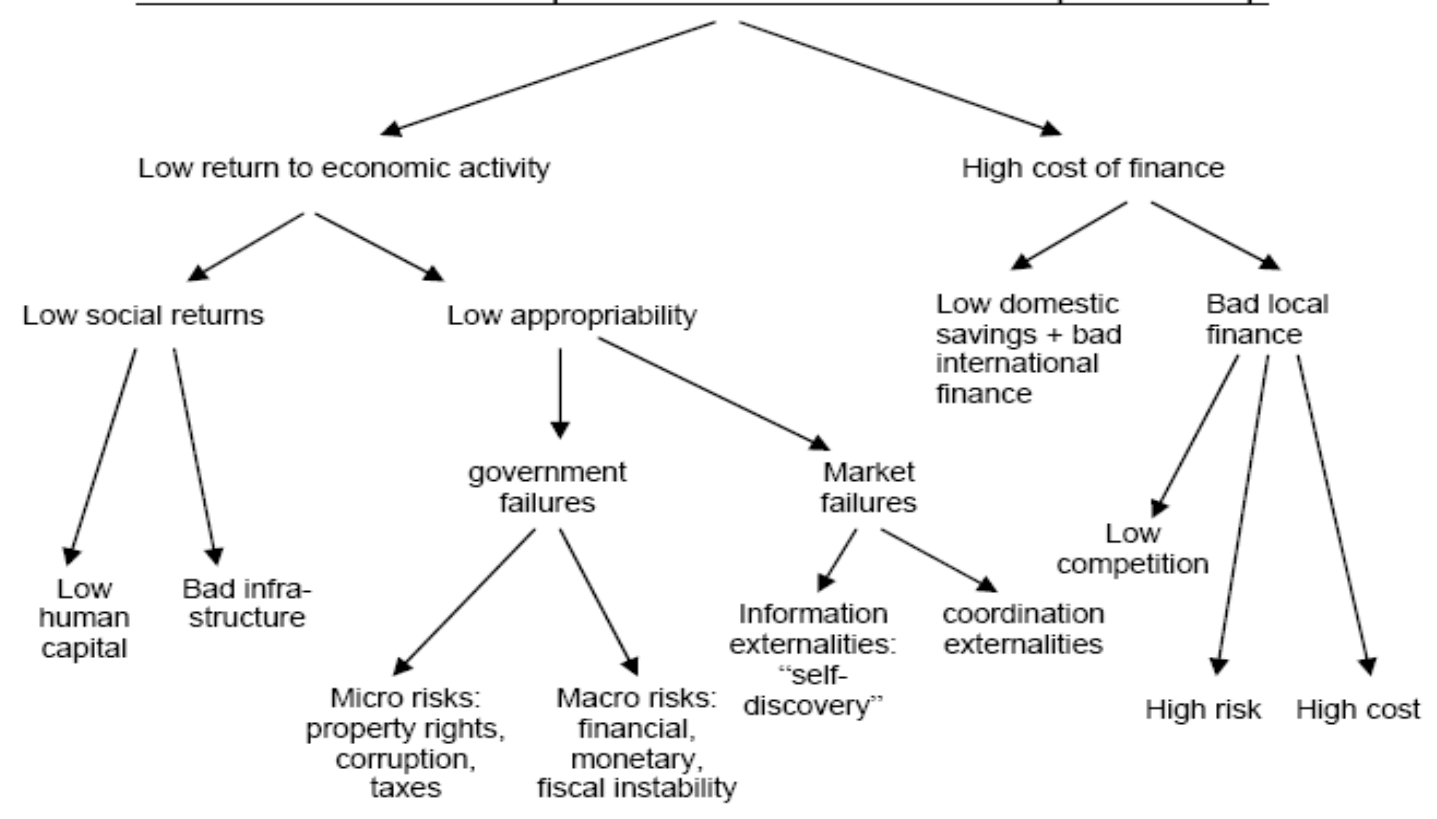

Source: Hausmann, Klinger, Wagner 2008.

The focus on policy implementation uncertainty also draws a link between the mainstream growth literature and firm level "policy uncertainty." A substantial branch of the growth literature argues that measures of "institutional quality" are related to economic growth (e.g. Acemoglu, Johnson, Robinson 2001). Even more strikingly, several recent papers have argued that when "institutions" and measures of "policies" (usually policy outcomes like budget deficits or inflation) are jointly included it is institutions not measured "policies" that matter for long-run economic growth (Rodrik, Subramanian and Trebbi 2004, Easterly and Levine 2003). As argued by Acemoglu, Johnson, Robinson and Thaicharoen 2003 at the macroeconomic level this is because macroeconomic symptoms like inflation are the result of institutional weaknesses, which results in both poor policy and poor policy implementation. Our argument is the microeconomic counterpart, low appropriability can inhibit growth and innovation not 
necessarily as the result of bad policy (e.g. tax rates that are "too high") but as the combination of policy with weak implementation so that the implementation of complex taxes results in substantial uncertainty.

The policy implementation interpretation links firms’ concerns about policy uncertainty and the suggestive evidence about the impact of uncertainty on firm employment growth with the growth literature, both the standard growth regression literature and the literature on episodic growth, generally (e.g. Hausmann, Pritchett, Rodrik 2005) and its application to Africa (Abarcha and Page 2007, Patillo et al. 2005) ${ }^{29}$.

\section{V.B) Programmatic responses: de jure "Policy Reform"}

As raising economic growth rates in Africa has been a development priority for decades, there have been clear responses, both programmatic and in overall reform efforts, to the major growth obstacles identified in the macroeconomic and microeconomic literature. Obviously addressing “macro instability”-reducing inflation, macroeconomic imbalances, exchange rate crises, debt—has been a major agenda for decades. "Access to finance” has been addressed through both big picture reforms of the financial sector and through programmatic attention to micro-credit and SME financing. Infrastructure and its shortages as obstacles to growth are also again attracting enormous attention and investments. Our argument is that inadequate conceptualization of the problem of policy implementation has hindered effective response to the problem of policy uncertainty ${ }^{30}$. It is not at all obvious that the typical approach to "policy reform" of

\footnotetext{
${ }^{29}$ For instance, Abarcha and Page (2007) find that a variety of indicators of “institutional quality” (the World Bank's CPIA and all six components of the KKM indicators) are lower during growth decelerations.

${ }^{30}$ One reaction to the empirical finding of consistently high levels of firms complaining of "policy uncertainty” is that the question was dropped from the standard Enterprise Survey instrument precisely because it was difficult to interpret the results and translate them into programmatic action.
} 
modest, incremental, reductions to policy barriers without quite dramatic changes in implementation can be effective in reducing policy uncertainty.

The Doing Business project has attempted to identify obstacles to private sector firms’ growth by examining the de jure regulatory environment that firms face. The existence of (reasonably) common indicators in both the Doing Business (derived from an examination of the regulations) and Enterprise Surveys (from firm responses) allows a comparison of the de jure notional policy mappings and reported de facto policy actions. ${ }^{31}$ Figure 5 shows the results for three indicators: time to get a construction permit (5a), days to start a business (5b), and time to import goods (5c). While there is not an exact correspondence of the respective concepts, there are nevertheless three striking points from these figures. One, there is almost no increase in the average enterprise survey reported days with respect to the Doing Business days. Clearly deals are prevalent. Two, there is, as documented above, large firm specific variability in the reported days but, even the reported delays de facto at the 95th percentile are far lower

\footnotetext{
${ }^{31}$ E.g. The Enterprise Surveys ask the "average time to clear goods through customs”, while Doing Business covers all the steps from the paperwork to port-handling and customs to delivery of the imported goods. The Enterprise Surveys ask "the number of days to get a construction permit", while Doing Business asks for all the days for all the procedures needed to comply with getting permission to construct a warehouse. It is possible that some of the gap between the ES and DB is due to additional procedures being covered in the DB than the ES. However, it is difficult to see how this could account for the lack of correlation of the variation in ES and the DB indicators across countries. We tested for the sensitivity using the time to import goods, subtracting off the time for inland transportation within the DB indicator. While the distribution shifted slightly to the left, there was little change in overall pattern.

Looking at the sub-indicators within each Doing Business indicator, there are some that are not just based on the interpretation of regulations on the books, e.g. inland transportion withing 'trading across borders'. For these sub-indicators, the lawyer or accountant that is making the evaluation provides an estimate, assuming that no intermediaries (legitimate or not) are used and no additional payments or bribes are paid. The size of the gap between the two sources of data illustrates how costly it would be not to try to strike a deal - and that assuming no deals are made does not reflect what in fact firms do given how far below the 45 degree line most observations are.

Another difference in methodology between the two datasets that should be kept in mind is that DB has a precisely defined firm conducting the transaction, e.g. 50 employees, domestically owned private company. The ES are a sample of firms - both larger and smaller than 50 employees. It is possible that some of the variation within country in the ES is that the regulatory requirements themselves vary by firm size. Only using firms close to the DB case could help improve the comparison, but the size of the samples is reduced dramatically - but will little change in the basic patterns reported.
} 
than the de jure days (around which, in the naïve positive model of complete compliance, one might expect to find the observations clustered). ${ }^{32}$ In Figure $5 b$ on days to start a business the top end $\left(90^{\text {th }}\right.$ percentile) appears to be about 60 days—-whether the de jure is $60,100,150$, or over 200 - as the DB days grow, the gap between DB and ES just grows one for one; the space for deals rises with the DB indicators. Three, the explanatory power of the reported Doing Business days for the realized policy action for a specific firm is very near zero. That is, whether a firm is in a country where the time to get a construction permit is 100 days or 500 days, there is almost no change in either the "expected value" or actual time nor much reduction in the observed variation. But there is evidence suggesting that the deals are more costly where the de jure rules are more burdensome; firms cannot fully escape the costs of greater regulatory burdens.

\footnotetext{
${ }^{32}$ The graphs exclude 'outside values' or outliers (approximately 5\% of the distribution.) In fact, not all countries have such outliers, and for those that do, many of them are below their DB measure. However, there are some firms whose reported experiences are greater than the Doing Business measures. Including them extends the scale, making it hard to see the inter-quartile ranges. Versions of these figures are available in the appendix with the outliers included.
} 
Figure 5: Variation across and within countries comparing the Doing Business days (on horizontal axis with each country observation on the $\mathbf{4 5}$ degree line) with the Enterprise Survey distribution of days (a box plot for each country)

5a) Time to get a construction permit (Doing Business) versus days get construction Permit (Enterprise Survey)

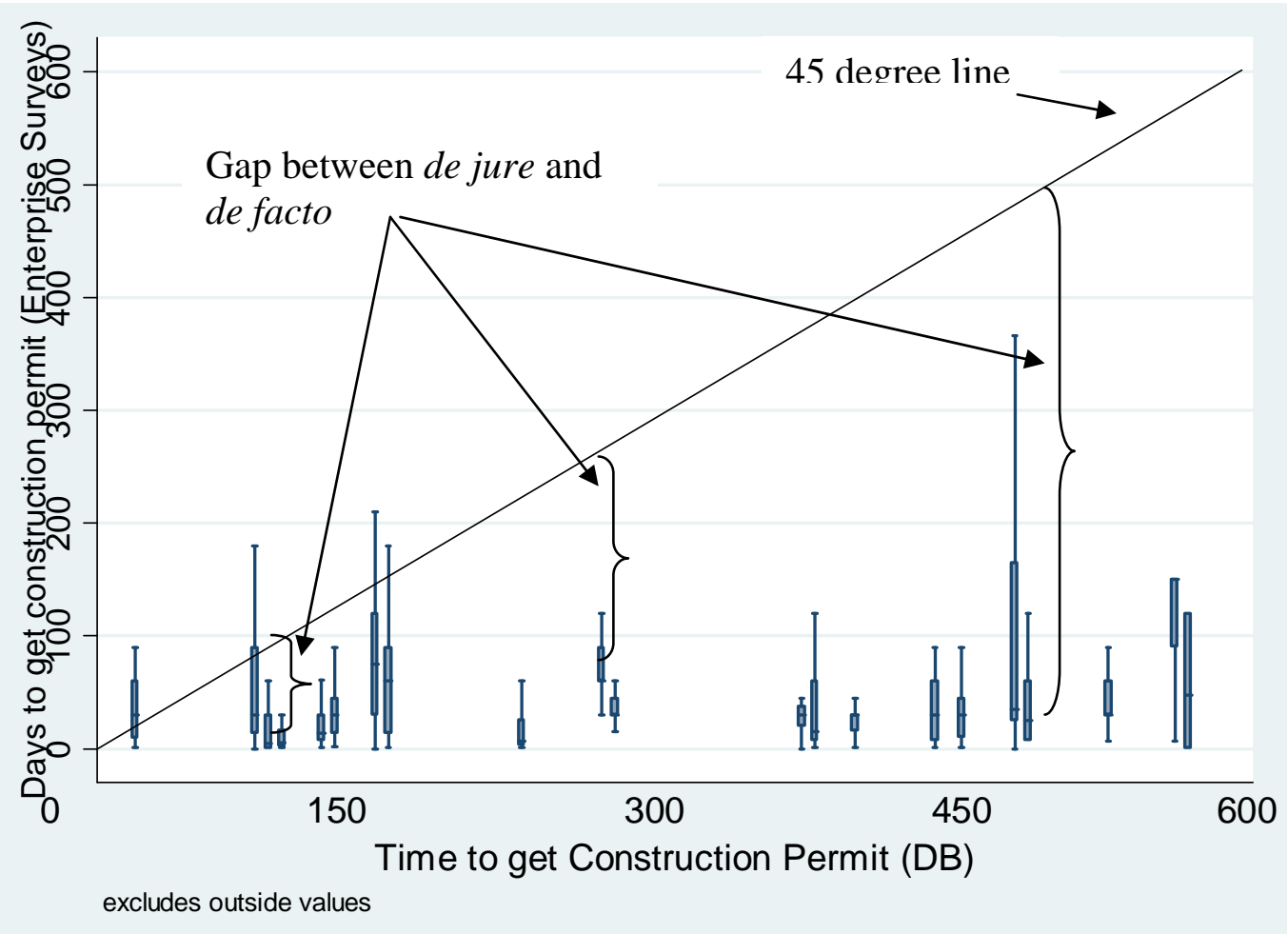


5b) Days to Start a business (DB) versus Days to Obtain an Operating License (ES)

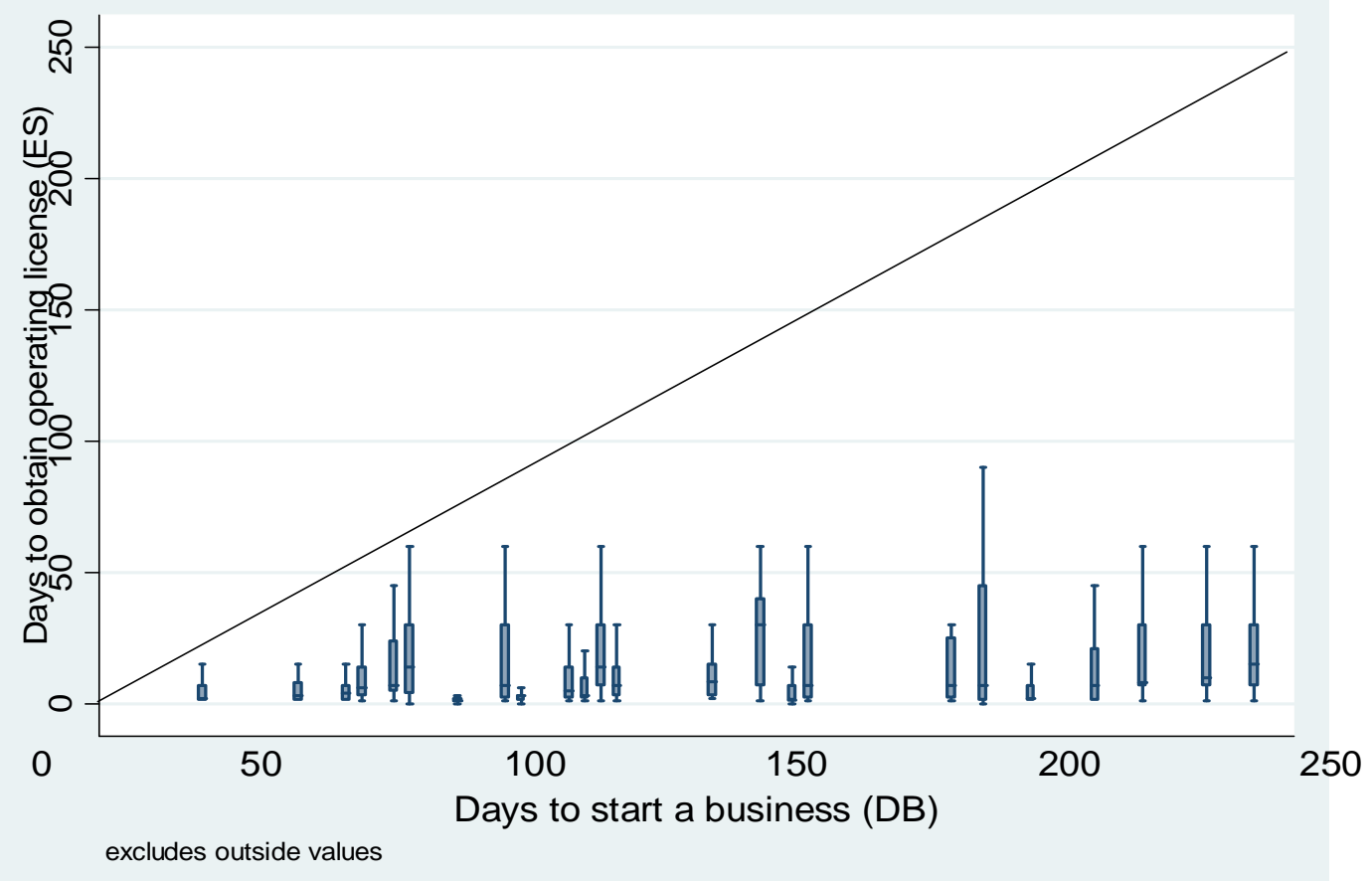

5c) "Time to Import Goods" (DB) versus "Days to Clear Customs" (ES)

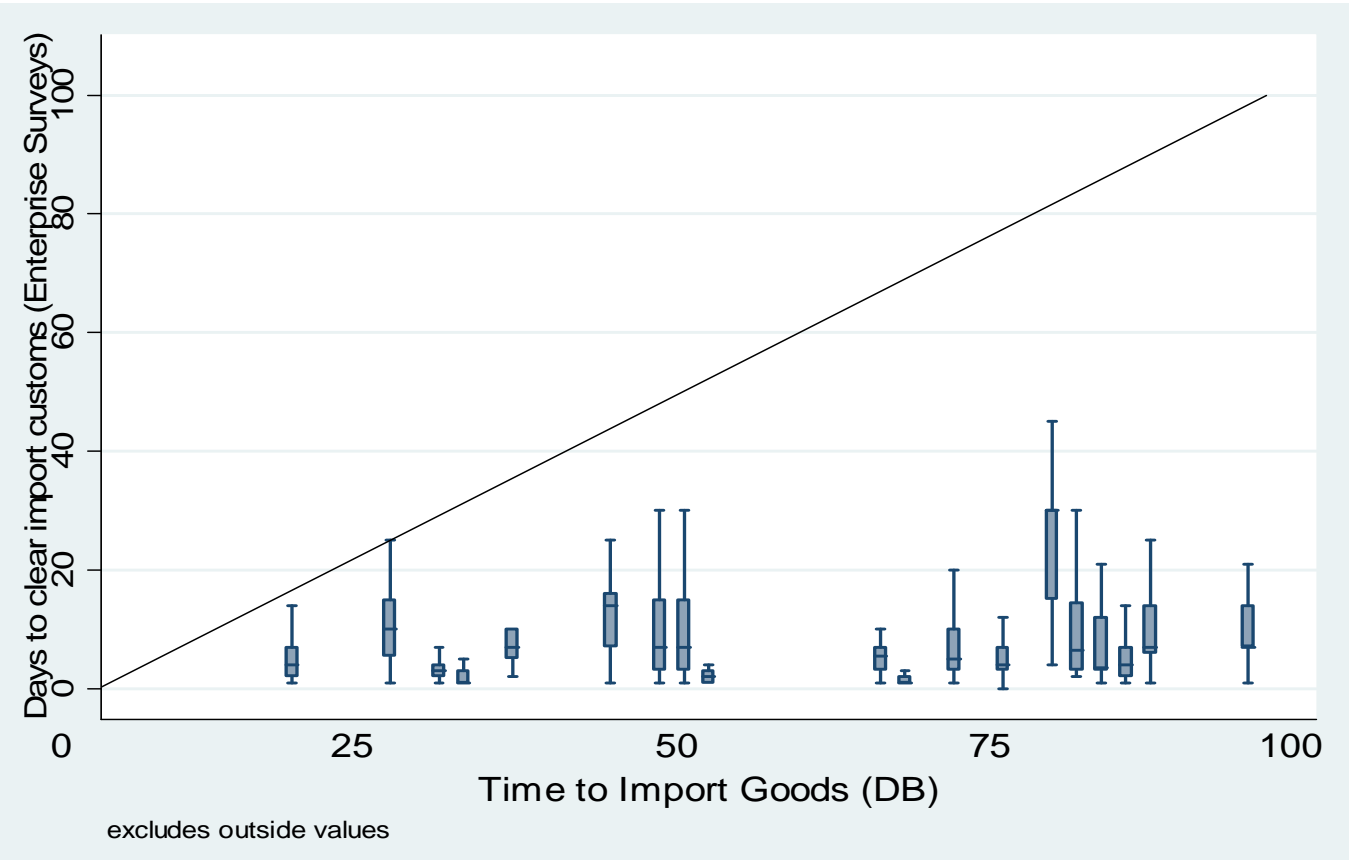


Table 9 shows the regression counter-part of the graphs in Figure 5 by asking, how much of a firms reported policy action is associated with the cross-national differences in the de jure reported policies. The country average of "policy" has almost exactly no explanatory power for the firm reported policy actions. Whether it took your firm a long time or a short time to get a construction permit or operating license or have imports clear customs has next to nothing to do with what the Doing Business survey reports about your country. This is not just a low-powered "failure to reject" as the hypothesis that the firm reported average increases one to one with the DB reported days can be decisively rejected for each indicator. ${ }^{33}$

Table 9: Correlation between firm's reported experience in the Enterprise Surveys and the de jure times in Doing Business

Enterprise Survey

\begin{tabular}{ccc}
\hline & Time to get & Time to get \\
$\begin{array}{c}\text { Time to get a } \\
\text { construction } \\
\text { permit }\end{array}$ & operating & imports \\
license for new & through \\
firms & customs \\
\hline
\end{tabular}

(3)

Doing Business

Time to get construction permit

Doing Business

Time to start a business

Doing Business:

Time to get imports through customs

Constant

$15.22 * * *$

$65.63 * * *$

$\mathrm{N}$

5401

1013

1759

R2

0.003

0.0134

0.002

$\operatorname{Pr}\left(\mathrm{H}_{0}: \beta=0\right.$, Firm reported days no association with de jure days)

0.0567

0.146

0.39

$\operatorname{Pr}\left(\mathrm{H}_{1}: \beta=1\right.$, Firm reported days increase one for one with de jure days)

0.000

0.000

0.000

\footnotetext{
33 The results are the same if one uses the Enterprise Survey country average or country median in the regressions.
} 
This complete lack of association raises questions about both the efficacy and political economy of the de jure "policy reform" approach to improving the investment climate. What is the expected aggregate firm response (in investment, in innovation, in output) to changes in the notional policy mapping about taxes, labor regulations, land use regulation, licensing requirements, import procedures, etc.? All existing firms have accommodated themselves to the existing environment and have made deals to do business (whether they are favored or disfavored in the deals process and whether the deal was expected to stay done or not). The question of the impact of de jure reform on firm performance may be like asking how much faster submarines will go if the wind blows harder: once you are under water (doing deals) changing the speed of the wind might have little impact.

On the other hand, there is evidence that while there appears to be little impact on the times firms report, there could be effects on the costs of the deals they have to strike. These relationships reported here are all in the cross-section, and a true test of the impact of a reform requires time series or panel data. But they are still telling: as the Doing Business indicator rises, both the average and the standard deviation of bribes paid rises (see Table 10). Thus reforming may not impact the days needed to comply with the regulation, but it could lower the cost of having to make a deal to avoid a less burdensome rule. 
Table 10: Deals are more costly where de jure rules are more burdensome.

\begin{tabular}{|c|c|c|c|c|c|c|}
\hline & $\begin{array}{l}\text { Bribes } \\
\text { Paid } \\
\text { (Av.) }\end{array}$ & $\begin{array}{l}\text { Bribes } \\
\text { Paid } \\
\text { (Av.) }\end{array}$ & $\begin{array}{l}\text { Bribes } \\
\text { Paid } \\
\text { (Av.) }\end{array}$ & $\begin{array}{c}\text { Std of } \\
\text { Bribes } \\
\text { Paid } \\
\end{array}$ & $\begin{array}{c}\text { Std of } \\
\text { Bribes } \\
\text { Paid } \\
\end{array}$ & $\begin{array}{c}\text { Std of } \\
\text { Bribes } \\
\text { Paid } \\
\end{array}$ \\
\hline Doing Business & 0.087 & & & 0.039 & & \\
\hline $\begin{array}{l}\text { Time to get construction } \\
\text { permit }\end{array}$ & $(0.083)$ & & & $(0.035)$ & & \\
\hline Doing Business & & $0.086^{*}$ & & & $0.040 *$ & \\
\hline Time to start a business & & $(0.050)$ & & & $(0.023)$ & \\
\hline Doing Business: & & & $0.172 * *$ & & & $0.079 * *$ \\
\hline $\begin{array}{l}\text { Time to get imports } \\
\text { through customs }\end{array}$ & & & $(0.078)$ & & & $(0.033)$ \\
\hline & -0.147 & 0.016 & -0.298 & 0.191 & $0.262 * * *$ & 0.120 \\
\hline Constant & $(0.446)$ & $(0.190)$ & $(0.281)$ & $(0.189)$ & $(0.087)$ & $(0.118)$ \\
\hline Number of observations & 31 & 40 & 31 & 31 & 40 & 31 \\
\hline $\mathrm{R} 2$ & 0.037 & 0.072 & 0.145 & 0.041 & 0.074 & 0.168 \\
\hline
\end{tabular}

One example on which there was detailed study is revealing. A comparison of the de jure processes of registering a new export business in Chile and Brazil revealed that the regulations in Brazil were complex and time consuming compared to the simpler process in Chile. This might have suggested reforming the rules in Brazil would lead to much greater exports. However, a detailed study (Stone, Levy, and Paredes, 1991) of the de facto processes of business registration in Brazil found that in practice businesses hired facilitators who made registration no more complex or time-consuming in Brazil than in Chile, and only moderately more expensive. The environment of open ordered deals—all firms could hire facilitators, the facilitators made the process predictable with little ex post uncertainty about the durability of the deal—actually replicated in many respects a regime of favorable rules-but perhaps at the expense of the policy purpose of the regulations.

We are not proposing that the impact of notional policy mapping reform on firm growth is zero, but it is far from obvious that modest (or even quite major) policy 
reforms, independently of changes in policy implementation, would have any impact on firm expectations of the policy actions that would result from implementation. ${ }^{34}$ The impact would depend critically on the previous situation — if it were one of open ordered deals this would have a very different impact than if the initial situation is disordered to which the policy reform is able to bring order. Of course, radical policy reform could drive the de jure regulation to zero or to the levels compatible with the existing organizational capability for implementation (which may be close to zero (Pritchett (2010)) and hence eliminate implementation uncertainty entirely (at least in that policy domain) but this is very different story as this requires sacrificing whatever policy purpose the regulation intended to accomplish.

A naïve view of the political economy of reform is that there is a broad coalition between agents interested in promoting economic growth: (economists, external assistance groups, potential foreign investors) and the domestic "business community" to improve the investment climate. However, in a deals environment this is far from obvious. Worse, in a closed ordered deals environment the economically and political powerful firms may have differentially favorable treatment in deals which gives them a competitive advantage over other firms, an advantage that would disappear in a rules environment. At least since Schumpeter’s Can Capitalism Survive? economists have realized that successful capitalists were not reliable supporters of capitalism, not

\footnotetext{
${ }^{34}$ On the other hand, the results can be interpreted as further evidence of the importance of streamlining and simplifying regulations. Excessive or burdensome requirements aren't being complied with or implemented consistently. Keeping them on the books only encourages deals and undermines the credibility of the regulations and the public interest goals they are 'supposed' to be protecting. Changing the formal rules may not result in much change in firm behavior if the earlier rules were not being implemented, but if the reforms themselves are a signal that the implementation regime will also be changing, then there could be effects. In further work we explore the relationship between the distribution of policy action outcomes pre and post-reform episodes for a wider set of countries. Within Africa, there are only a few examples of panel datasets that capture pre and post reform periods. Looking at the Cameroon and Uganda, we find the dispersion actually increases post reform.
} 
particularly caring for the "destruction” half of creative destruction. Rajan and Zingales (2003) for instance emphasize that incumbent firms often favor a weak financial sector, unable to reallocate resources into new (potentially threatening) innovations. Hellman, Jones, and Kaufmann (2000) argue that in the transition to "better" policies in the transition countries the shift in the institutional environment create opportunities for massive "closed" deals in which forces "seized the state" and then used it to favor their economic interests in both policy implementation and policy formulation. And even worse than these problems with favored firms, even among the disfavored firms there is the problem of coalition formation to lobby to change a rule when in a deals environment one can buy/lobby/influence policy implementation ${ }^{35}$.

\section{V.C) Reducing policy uncertainty}

Given the variation across firms in the reported predictability of implementation and the associated spreads in actual policy outcomes across firms in the same location, it is not surprising any given firm's outcome is uncorrelated with measures of the formal rules. Of interest is to know if the individual outcomes are correlated with other dimensions of regulations, namely assessments of the ability to implement rules. Figures $6 \mathrm{a}$ and $6 \mathrm{~b}$ show the correlation of the share of firms reporting implementation is consistent and the standard deviation within the location-sector-size cells with measures of Government Effectiveness and Control of Corruption (Worldwide Governance Indicators, World Bank). If Government Effectiveness or Control of Corruption provides

\footnotetext{
35 Moving beyond this naïve political economy there may be reasons for external actors (e.g. donors, foreign firms) to push for more favorable de jure rules rather than focus on policy implementation. Official external agencies are more comfortable dealing with rules as focusing on implementation would have to confront the massive deviation of de jure and de facto and its causes, which is a more awkward topic that technically neutral "policy reform." Foreign firms might prefer rules to deals if they have a competitive disadvantage in local deals. Administrative simplification of large enough magnitude to make compliance a feasible option might level the playing field for foreign firms.
} 
greater certainty, one would expect a positive association with the average level of consistency reported and a negative association with the variation. Indeed, this is what we find. So building institutional capacity may well be one way to address policy uncertainty.

While policy implementation uncertainty is related institutional performance and government efficacy, these evolve slowly. Are there ways to shift expectations about policy uncertainty in the short run? We wish to address two, definitive policy shifts (often associated with clear political shifts) or the use of a selective reduction of policy obstacles for favored firms. 
Figure 6a: Reported Consistency (Share that report implementation is consistent, and the standard deviation in degree of consistency) and Government Effectiveness
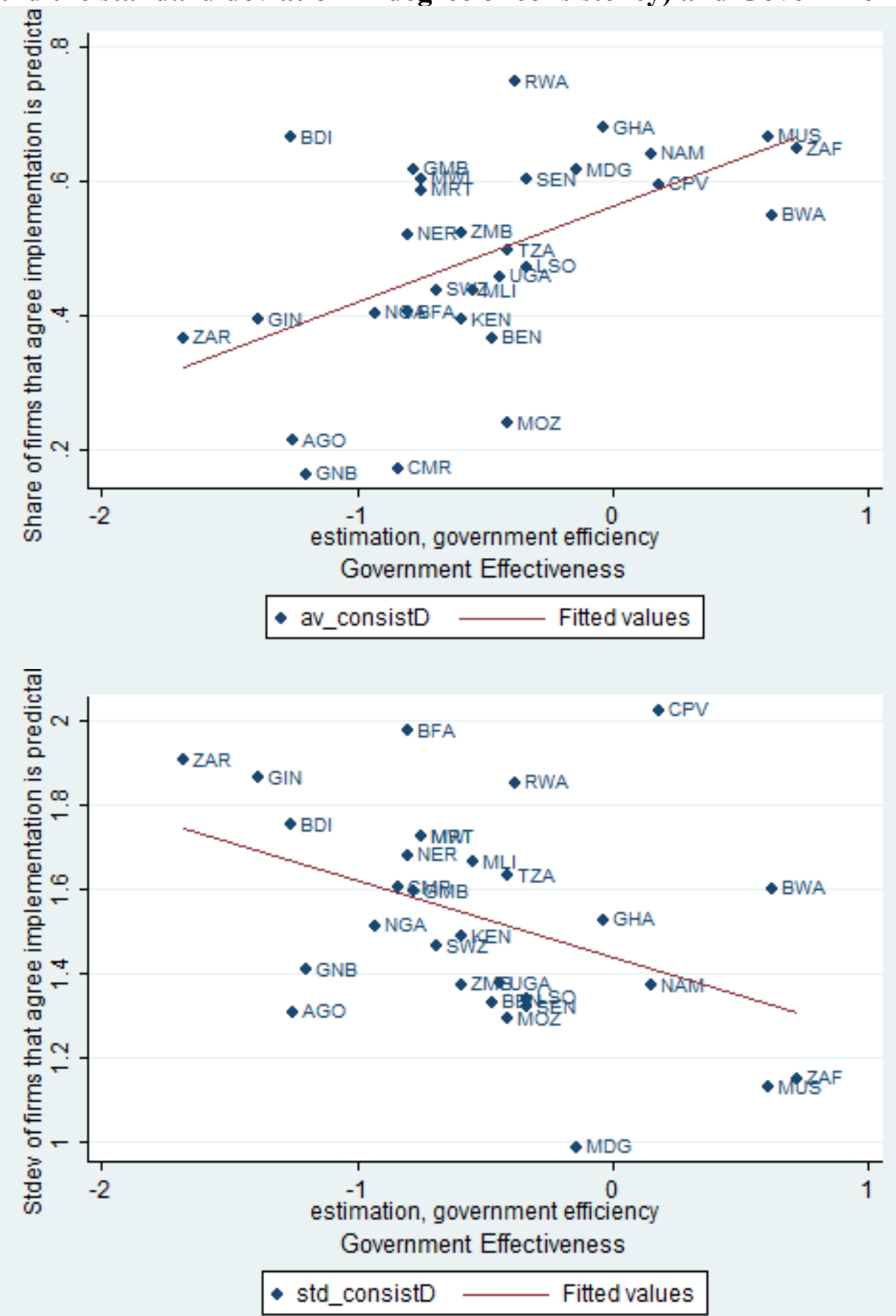
Figure 6b: Reported Consistency (Share that report implementation is consistent, and the standard deviation in degree of consistency) and Control of Corruption
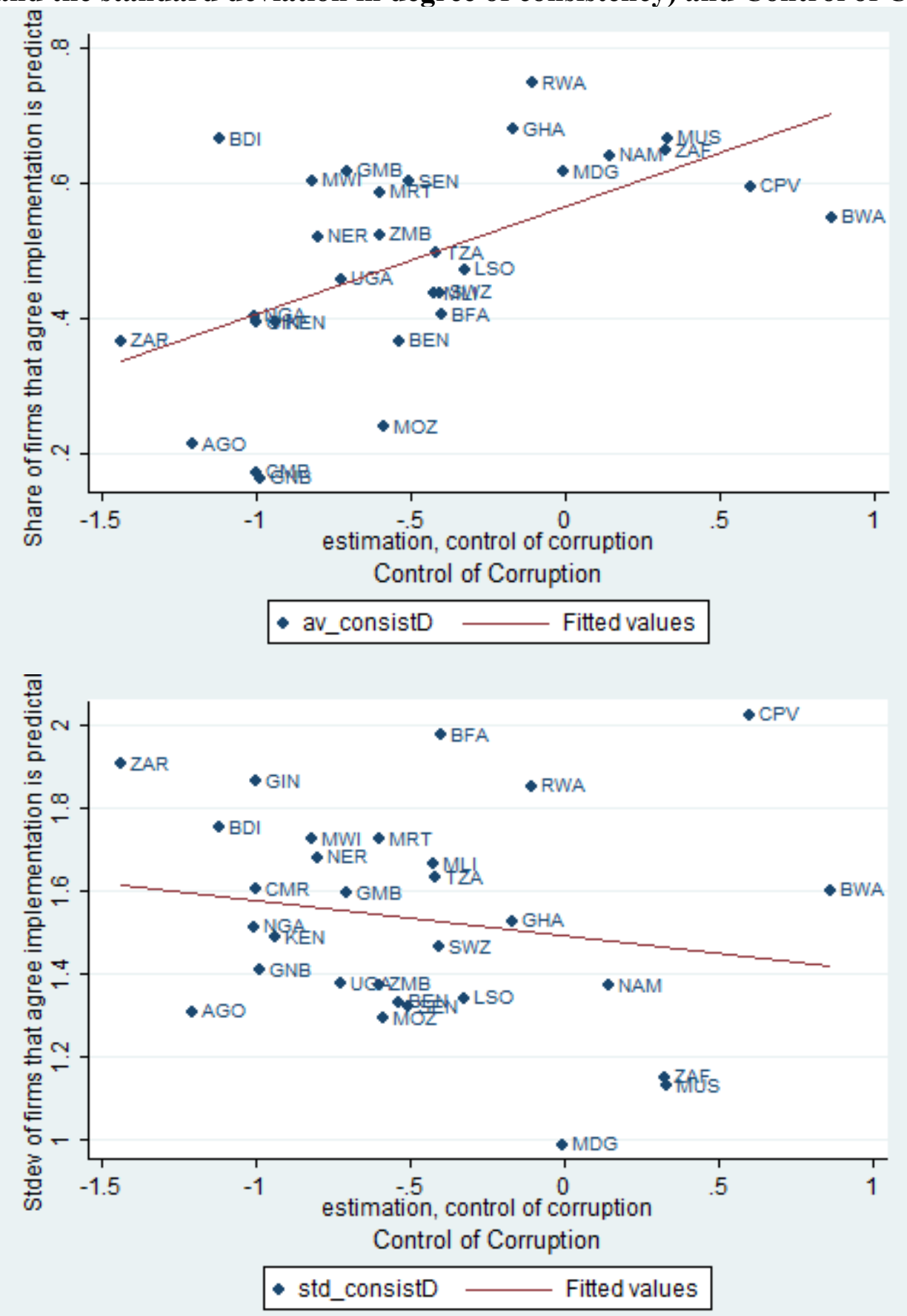

Source: Authors calculation, Enterprise Surveys and Worldwide Governance Indicators

Decisive shift to a "pro-business" environment. As Shleifer and Vishny (1993) have pointed out, it is not obvious that compliance with "rules" or a lack of corruption is either 
a necessary or sufficient condition for rapid growth. Many of the world's episodes of extremely rapid growth have occurred in environments in which corruption was pervasive and "closed ordered deals" was the basic structure of the formal economy (with smaller firms exposed to mostly to a dual economy with “open ordered deals” as long as their operations were not a threat). The economic successes of Indonesia from 1966 to 1997 or of South Korea in the 1960s (Haggard, Kim, and Moon, 1990)—among others-were clearly not the result of an absence of corruption. The rapid growth of countries today such as China, India (or even more strikingly the more modest but still impressive growth of Bangladesh) can hardly be attributed to a lack of corruption. In fact, one could argue that "closed ordered deals" environment in which the interests of certain large industrial enterprises are well represented in policy making and policy implementation, whether officially (as in the large industrial groups of Japan and Korea (Wade 1990, Evans 1995)) or unofficially (with the preferred conglomerates in Indonesia) can lead to more responsive government action on key dimensions, a de facto "high bandwidth" policy making (Hausmann 2008).

There are African examples of dramatic turn around in policy implementation uncertainty. After the 1994 genocide in Rwanda, the country experienced a rapid recovery to pre-conflict levels of investment (Figure 6), which is typical in post-conflict countries. But in Rwanda another investment boom followed and capital formation is now at roughly twice the pre-conflict level. Even more remarkable for a small, landlocked nation in an unstable region it has also managed to attract significant foreign direct investment. They did this not only by fighting corruption very aggressively, which increased the credibility of government policy implementation, but also by 
prioritizing specific deals. Rwanda's success in sequencing its reforms was in part due to a long-term vision of policy framework and development goals outlined by the government. Rwanda Vision 2020 provides a policy framework to reform that allows for consistency and reduces the inter-temporal policy risk faced by private investors.

\section{Figure 6: Evolution of investment in Rwanda following the conflict and}

\section{genocide}

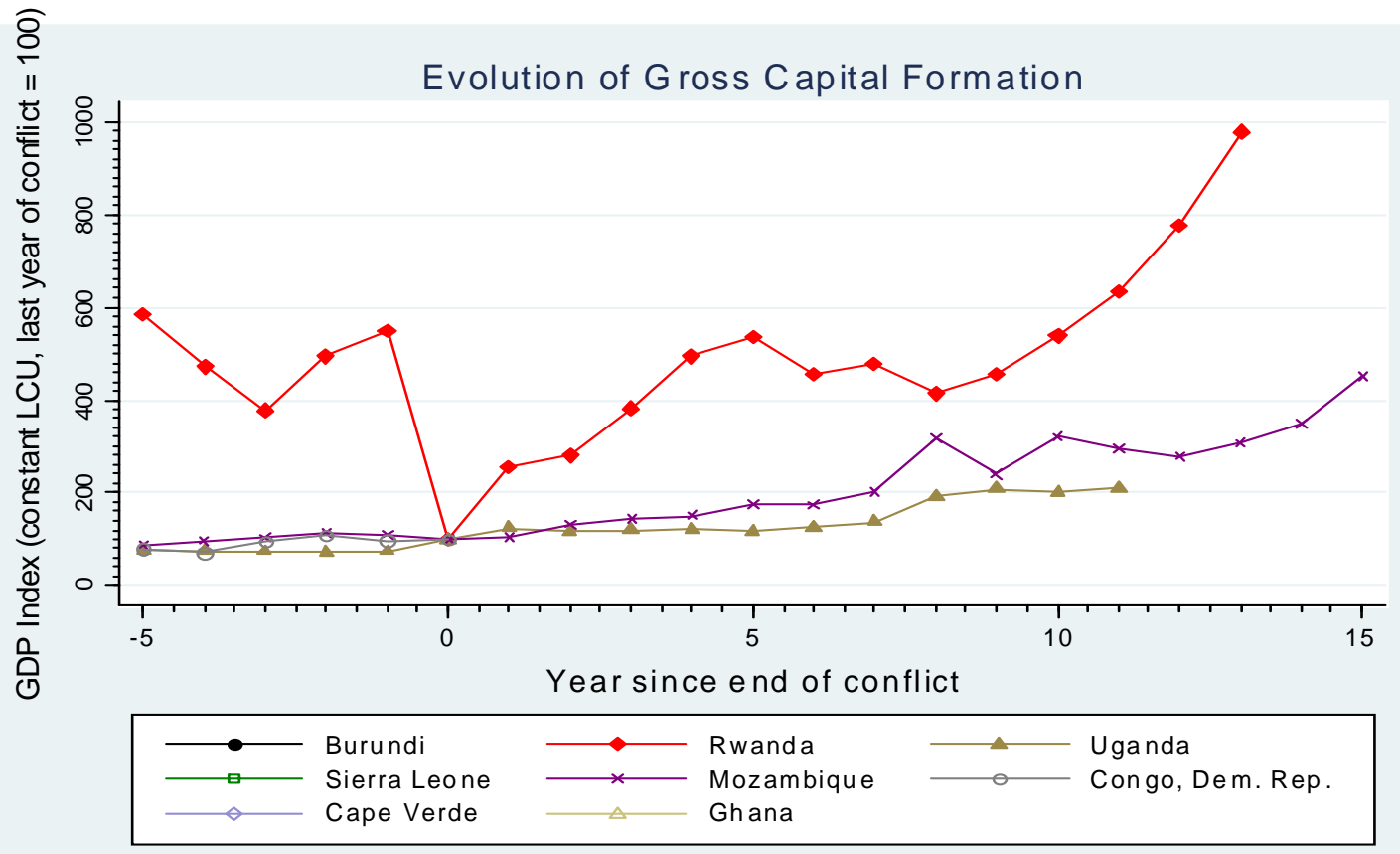

Source: WDI

In the past 10 years, Rwanda has made significant progress in both simplifying the rules and in enforcing them effectively, as can be seen in the cross-national tables above. In Rwanda 90 percent of firms believe regulations are enforced "consistently and predictably” (Figure 3), the level and variability of days to get an operating license are among the lowest (Figure 2a and 2b), and in Rwanda, less than 5\% of the firms identify corruption as a constraint, according to the World Bank Enterprise Survey 2006, 
compared to $73 \%$ of firms in Kenya or 50\% of firms in neighboring Tanzania and only 20 percent report paying bribes (fourth lowest).

Rwanda prioritized enforceable policies, avoiding the common practice ignoring enforcement capability and promulgating a long list of complex laws that are not reliably enforced opening space for deals and uncertainty. Rwanda's judicial system reform since 2001 is an example improving institutions while maintaining stability. The country transitioned from its colonialist inherited civil law system to common law, in the process both reducing the length of procedures (from 5 to 10 years down to only 2 to 3$)^{36}$ and increase the reliability of the court system. In the 2006 Enterprise Survey data 67\% of firms believed their court system is fair, impartial, and uncorrupted (compared to only $16 \%$ in Mozambique or 22\% in Kenya and 25\% on average).

Rwanda did more than improving the overall climate, the government also made specific deals with mostly US-based multi-national companies and were able to rapidly increase its exports significantly (mainly with the US). The increase in trade due to these targeted agreements was bigger than multi-lateral trade agreements, such as the African Growth and Opportunity Act (AGOA). The most prominent deal was in Rwanda's coffee sector. Recognizing the importance of the coffee sector for its economy (especially exports) as well as providing stable income for farmers, Rwanda conducted high-level talks and negotiated special agreements with big importers of coffee from the United States. These specific deals achieved a bigger result than a traditional bilateral countryto-country trade agreement. On one hand, the government addressed the basic needs of the coffee importers, such as security and reliability, and on the other hand, it helped

\footnotetext{
${ }^{36}$ Overhauling Contract Enforcement: Lessons form Rwanda BIZCLIR: Business Climate Legal \& Institutional Reform, Issue 17, March 2007
} 
coffee growers meet quality standards for export. Rwanda's highest-level government leaders approached directly the heads of specific coffee-roasting companies in the US, such as Starbucks, and CostCO. Rwanda has attracted unlikely investors such as Better Place, a California-based start-up company that produces batteries for electric cars. Given that Rwanda imports electricity itself, the presence of such companies is testament to the country's gain in credibility and improved business environment.

Special initiatives to reduce policy uncertainty. The risk of country-wide approaches to improving credibility is that they often hinge on the credibility of a specific regime or individual, such as Kagame in Rwanda, and experience has shown that this credibility is often very difficult to depersonalize and institutionalize (not to mention the political ramifications). An alternative to either across the board de jure reform or across the board agendas is to pursue the creation of reliable implementation incrementally. That is, while the goal is to reduce policy uncertainty overall, one can start by focusing on specific spaces, specific policy domains, or specific types of firms.

For instance, the traditional approach to special economic zones was to create enclaves strictly for production for export. However, the Chinese appear to have used them on a much larger scale as a device to introduce different policy sets and expectations about implementation that did not require taking on entrenched interests immediately. The idea of "charter cities" (Romer 2009) is in some sense a natural, if audacious, extension of this notion that policy implementation is important in creating an environment capable of sustaining high productivity firms and dense economic transactions but at the same time policy implementation is difficult to reform wholesale in situ. 
An alternative approach is to focus on particular policy domains and attempt a simultaneous reform of policy and policy implementation, something like an "island of integrity” approach. One could begin with a policy domain that firms find particularly egregious. However, if firms are caught up in multiple regulatory domains it may be that the policy incremental approach will be limited. Certainly the litany of failures with the introduction of special economic zones of various types suggests special zones are not intrinsically special. Governments that lack the credibility to commit to good policy implementation may also lack the credibility to commit to good policy implementation even in a "special” zone.

The final alternative is to identify firms engaged in prioritized activities and rather than pursue traditional “industrial policy” instruments such as subsidies or credit or privileged tax status make them the focus of implementation reform. In reality this is just making the de facto situation of closed deals more ordered and hopefully creating some degree of transparency and rationality to the selection of the firms/industries/sectors for which policy implementation reform is a priority.

\section{Conclusion}

Firms hate "regulatory and policy uncertainty." We argue this is more than just disliking "bad policy" and more than inter-temporal changes in the rules. We argue that what firms dislike is that doing business in countries with weak capability for policy implementation consists of a set of specific, potentially complex, inter-related, deals with the various agencies of the state. As we document, this results in huge ex post variability in policy actions that are not predicted by policy. Many firms face a closed environment, in which deals are limited to firms with favored characteristics and/or a disordered 
environment in which it is difficult to reliably predict policy action outcomes, even when firms undertake influence activities. This conceptual shift to thinking about the firm specificity for the space for deals—rather than an abstract country "environment” of better or worse general rules-helps both in reconciling the micro-economic and macroeconomic literatures on institutions and policies, and, more importantly, in thinking through innovative ways of addressing policy uncertainty, even with institutions that are capable only of gradual change. 


\section{References}

Acemoglu, D., S. Johnson and J. Robinson, "The Colonial Origins of Comparative Development: An Empirical Investigation.” The American Economic Review, Vol. 91, No. 5 (Dec., 2001), pp. 1369-1401.

Acemoglu, D., S. Johnson, J. Robinson and Y. Thaicharoen, 2003. "Macroeconomic Volatility, Institutional Causes: Volatility, Crises, and Growth.” Journal of Monetary Economics. 50(1), pp 49-123.

Arbache, J. and J. Page. 2007. "More growth or fewer collapses? A new look at long-run growth in Sub-Saharan Africa,” World Bank Policy Research Working Paper \#4384.

Aterido, R., M. Hallward-Driemeier and C. Pages. Forthcoming. "Big Constraints to Small Firms’ Growth?” Economic Development and Cultural Change.

Beck, Thorsten, Asli Demirgüç-Kunt and Vojislav Maksimovic. 2005. "Financial and Legal Constraints to Growth: Does Firm Size Matter?” Journal of Finance 60(1): 131-177.

Bertrand, M, S. Djankov, R. Hanna, S. Mullainathan. 2007. “Obtaining a Driver’s License in India: An Experimental Approach to Studying Corruption.” Quarterly Journal of Economics. 122(4). Pp. 1639-1676.

Bigsten, Arne and Måns Söderbom. 2006. “What Have We Learned from a Decade of Manufacturing Enterprise Surveys in Africa?” World Bank Research Observer 21(2). Pp. 241-265.

Dollar, David, M. Hallward-Driemeier and T. Mengistae. 2005. "Investment Climate and Firm Performance in Developing Economies.” Economic Development and Cultural Change 54. pp. 1-31.

Easterly, W. and R. Levine. 2003. “Tropics, Germs and Crops: How Endowments Influence Economic Development,” Journal of Monetary Economics. 50(1), pp. 3-39.

Evans, Peter. 1995. Embedded Autonomy: States and Industrial Transformation. Princeton University Press.

Fafchamps, Marcel. 2004. Market Institutions in Sub-Saharan Africa: Theory and Evidence. MIT Press: Cambridge MA.

Fisman, Raymond. 2001. "Estimating the Value of Political Connections.” American Economic Review. 91(4). Pp 1095-1102. 
Gonzalez, Alvaro, Ernesto Lopez-Cordova, and Elio Valladares. 2007. "The incidence of graft on developing-country firms”. World Bank Policy Research Working Paper 4394.

Greif, Avner. 2006. Institutions and the Path to the Modern Economy. Cambridge University Press.

Hallward-Driemeier, M. and L. Pritchett. 2010. "Water in the Regulations." Forthcoming.

Hausmann, R. 2008. “The Other Hand: High Bandwidth Development Policy.” HKS Working Paper 08/060.

Hausmann, R., B. Klinger, and R. Wagner. 2008. “Growth Diagnostics: A Mindbook.”

Hausmann, R., L. Pritchett, and D. Rodrik. 2005. “Growth Accelerations.” Journal of Economic Growth. 10(4), pp. 303-329.

Hausmann, R. and D. Rodrik. 2002. “Economic Development as Self-Discovery.” NBER Working Paper 8952.

Johnson, Simon. 2009. “The Quiet Coup.” The Atlantic (May).

Kaufmann, Daniel, M. Mastruzzi, and D. Zavaleta. 2003. "Sustained Macroeconomic Reform, Tepid Growth: A Governance Puzzle in Boliva?” in In Search of Prosperity: Analytical Narratives on Economic Growth. D. Rodrik ed. Princeton University Press: Princeton NJ.

North, Douglas, John Joseph Wallis, and Barry Weingast. 2009. Violence and Social Orders. Cambridge University Press: New York New York.

Pressman, Jefferey L. and Aaron Widlavsky. 1973. Implementation. University of California Press. Berkeley CA.

Patillo, C., S. Gupta and K. Carey. 2005. "Sustaining Growth and Pro-Poor Growth Accelerations in Sub-Saharan Africa,” IMF Working Papers WP/05/195.

Pritchett, Lant. 2005. "Reform is Like a Box of Chocolates.” Mimeo.

Pritchett, Lant. 2010. “The Dangers of Paper Tigers.” in Frances Fukuyama and Nancy Birdsall, eds. Lessons of the Financial Crisis for Developing Countries.

Pritchett, Lant and Geeta Sethi. 1993. “Tariff Rates, Tariff Revenue and Tariff Reform: Some New Facts.” World Bank Economic Review 8:1, pp 1-16. 
Rodrik, Dani, A. Subramanian, and F. Trebbi. 2004. “Institutions Rule: The Primacy of Institutions over Integration and Geography in Economic Development.” Journal of Economic Growth. 9(2), pp. 131-165.

Romer, Paul. 2009. Charter Cities.

Schumpeter, Joseph. 1942. Can Capitalism Survive? Harper and Row.

Sequeira, S. and S. Djankov. 2010. “An Empirical Study of Corruption in Ports.” Forthcoming.

Shliefer, Andrei and Robert Vishny. 1993. “Corruption.” Quarterly Journal of Economics, 108(3). Pp. 599-617.

Slinko, I, E. Yakolev, and E. Zhuravaskaya. 2005. "Laws for Sale: Evidence from Russia.” American Law and Economics Review. 7(1), pp 284-318.

Smith, Warrcik and Mary Hallward-Driemeier. 2005. "Understanding the Investment Climate.” Finance and Development (March).

Wade, Robert. 1990. Governing the Market: Economic Theory and the Role of Government in East Asia. Princeton University Press.

World Bank. 2008. Worldwide Governance Indicators. 
Appendix: Enterprise Surveys and Doing Business - including the outliers These figures reproduce figures $5 a-5 c$ in the text, but include the outside values. The 45 degree line is included to show that the vast majority of firms face conditions less burdensome than the formal requirements (the solid lines represent at least $95 \%$ of the firms in a country).

\section{5a -II) Construction Permit}

\section{5b II) Operating License}

(Note: In two countries (with $\mathrm{DB}<100)$ a firm reported having delays of over a year in getting their license; they were included but capped at 1 year to keep the scale from becoming too large.
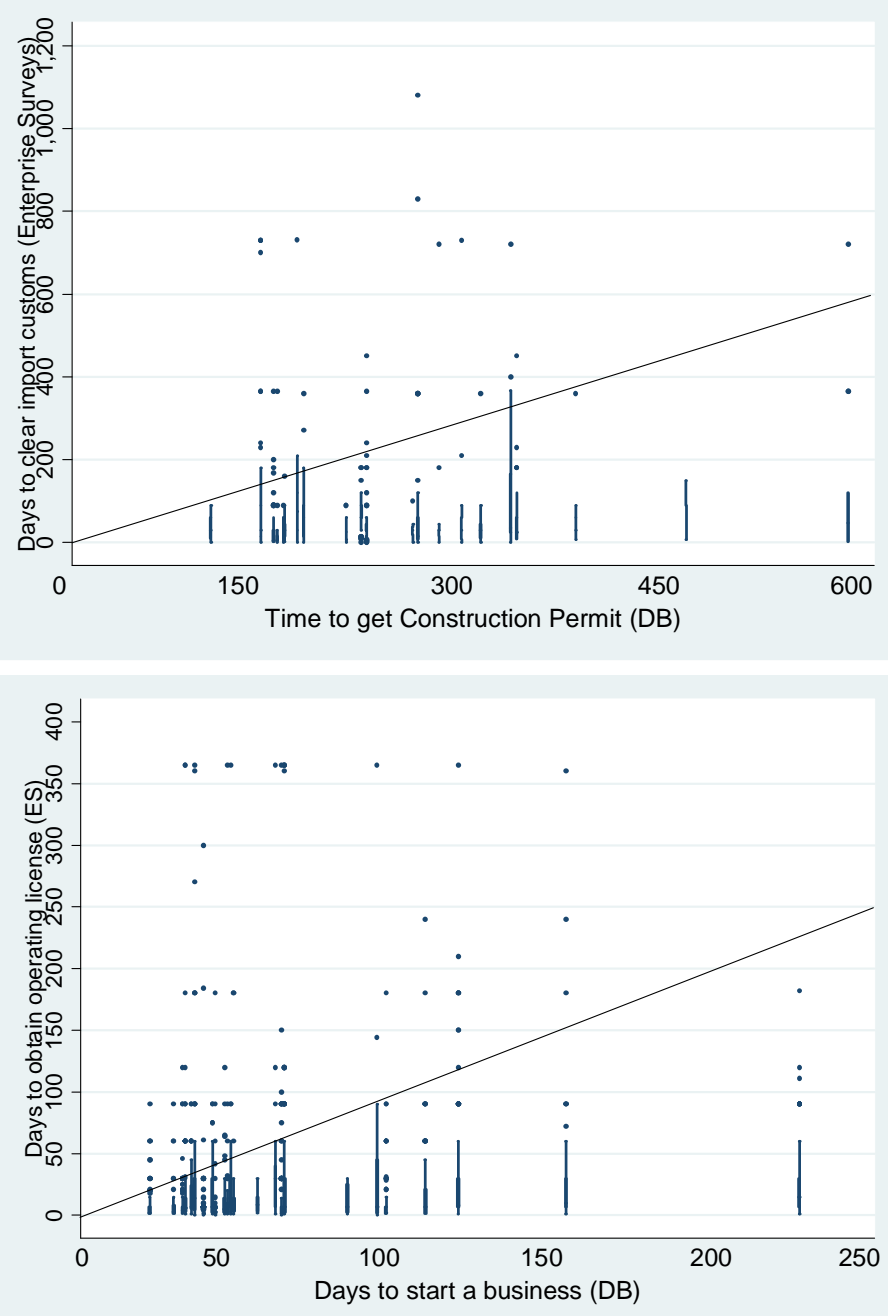

\section{5c-II) Clearing customs}

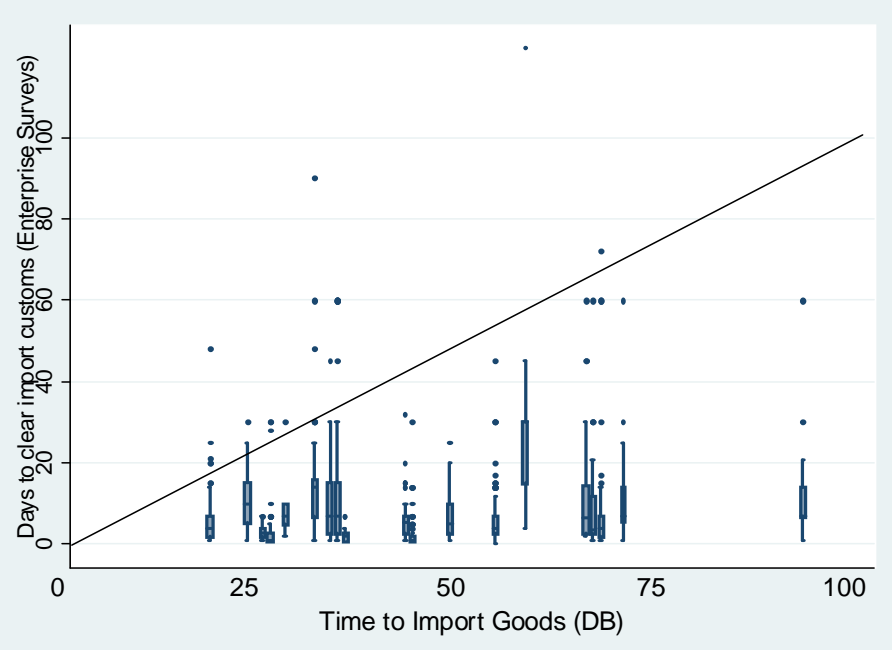

